${ }_{1}^{1}$ Dr. Öğr. Üyesi, Sabancı Üniversitesi, İstanbul, Türkiye,

nufer.ates@sabanciuniv.edu

ORCID: 0000-0003-4572-4101

Başvuru/Submitted: 18/07/2021

Revizyon/Revised: 12/09/2021

Kabul/Accepted: 10/10/2021

Yayın/Online Published: 25/12/2021

Atıf/Citation: Ateş, N.Y., Strateji uygulama yetkinliği: Brisa strateji süreci vaka incelemesi, bmij (2021) 9 (4): 1315 1334, doi:

https://doi.org/10.15295/bmij.v9i4.1891

\section{Strateji uygulama yetkinliği: Brisa strateji süreci vaka incelemesi}

\author{
The strategy implementation competence: A case analysis of Brisa's \\ strategy process
}

\author{
Nüfer Yasin Ateş ${ }^{1}$
}

\section{Öz}

Strateji uygulama yetkinliği - bir organizasyonun eylemlerinin stratejik niyetleri ile örtüşme derecesi- organizasyonun stratejik hedeflerine ulaşması için çok önemlidir. Ancak, organizasyonların strateji uygulama yetkinliklerini nasıl geliştirebilecekleri hakkında yeterince çalışma bulunmamaktadır. Bu araştırma, strateji uygulama yetkinliğinin öncülleri ile ilgili bir teorik çerçeve geliştirmeyi ve bu çerçevenin uygulamasının bir ampirik vaka çalışması ile göstermeyi amaçlamaktadır. Strateji uygulama yetkinliği kavramı geleneksel strateji süreci yaklaşımıyla kıyaslanarak tanımlanmış ve üç öncülü stratejik katılım, uyum ve bağllık olarak belirlenmiştir. Strateji uygulama yetkinliğinin öncülleri ile ilgili geliştirilen bu teorik çerçeve lastik sektöründe faaliyet gösteren uluslararası bir firma olan Brisa Bridgestone Sabancı Lastik ve Ticaret A.Ş'nin strateji süreci ile ilgili bir vaka analizinde tatbik edilmiştir. Vaka analizi bulguları, stratejilerin tüm kademelerden yeni önerilerin ortaya çıkmasına imkân verecek şekilde yüksek katılım ile belirlenmesinin ve süreç katılımcılarının stratejilerin arkasında yatan niyetler hakkında ortak anlayışa ve stratejilere bağlılığa sahip olmalarının kurumun üstün strateji uygulama yetkinliğine işaret ettiğini göstermektedir.

Anahtar Kelimeler: Stratejik Yönetim, Strateji Süreçleri, Stratejilerin Uygulanması, Yetkinlikler, Vaka Analizi

Jel Kodlar1: M10, M19, L21

\begin{abstract}
Strategy implementation competence, defined as the alignment between an organization's actions and strategic intentions, is central in achieving long term strategic goals. However, the extant literature on how organizations can improve their strategy implementation competence is scarce. This research aims to develop a theoretical framework about the antecedents of strategy implementation competence and demonstrate its application in a single case study. After positioning the strategy implementation competence view compared to the traditional strategy process approach, we identify three antecedents of the concept: strategic involvement, alignment, and commitment. We illustrate how these antecedents are associated with the strategy implementation competence in a leading international firm in the tire industry: Brisa Bridgestone Sabanci Lastik ve Ticaret A.S. The case study results show that strategic involvement from multiple hierarchical levels enables strategy implementation competence. In addition, organizational members' shared understanding of corporate strategies and their commitment to strategies induce strategy implementation competence.
\end{abstract}

Keywords: Strategic Management, Strategy Processes, Strategy Implementation, Competences, Case Study

Jel Codes: M10, M19, L21 


\section{Extended Abstract}

\section{The strategy implementation competence: A case analysis of Brisa's strategy process}

\section{Literature}

Strategy plays a central role in organizational survival and performance (Porter, 1997, 2008). However, regardless of how well it is designed, any strategy is ineffective unless successfully executed (Noble, 1999). Organizations often attribute strategic failure to external conditions such that a competitor introduces a new product in the market, customer preferences change unexpectedly, or the market shrinks (Jordan and Audia, 2012; Sedikides and Gregg, 2008). However, they neglect their strategy implementation capabilities (Kotter, 1995; Lee and Puranam, 2016). Earlier research reports that more than fifty per cent of organizational decisions fail due to implementation rather than formulation (Nutt, 1999).

Strategy formulation and implementation are two phases of a strategy process (Hutzschenreuter and Kleindienst, 2006). The traditional strategy process approach considers a dichotomy between formulation and implementation: top managers formulate strategy, and other organizational layers implement it (Wooldridge, Schmid and Floyd, 2008). However, later research established the role of the broader scope of corporate actors and the intertwined nature of strategy formulation and implementation (Floyd and Lane, 2000; Raes, Heijltjes, Glunk and Roe, 2011; Wooldridge et al., 2008). Building on this line of research, we define strategy implementation competence as the alignment between organizational actions and strategic intentions.

Because strategy formulation already considers the organisation's strategic intentions, the exact implementation of formulated strategies might be assumed to align organizational action and strategic intentions (Noble, 1999). However, this assumption only holds when effective strategies can be precisely formulated. Under uncertain, ambiguous, volatile and complex external circumstances, it is not realistic to assume the boundedly rational managers can formulate undoubtedly effective strategies (March and Simon, 1958). Moreover, any strategy may lose its appeal when external events unfold, and states of nature are manifested (Lee and Puranam, 2016). Therefore, rather than perfecting formulating the best strategies, this research focuses on improving the strategy implementation competence of organizations.

Strategy implementation competence enhances organizational adaptability by fueling strategic renewal. Despite its importance, strategy implementation received limited scholarly attention. This research aims to develop a theoretical framework that identifies the antecedents of strategy implementation competence. The research question concerns how organizations improve their strategy implementation competence.

Our theoretical framework proposes three antecedents for strategy implementation competence: (i) broad scope of involvement in the strategy process, (ii) strategic alignment between and within organizational units, and (iii) commitment of organizational actors to strategies. This framework adds to the literature that positions strategic planning as a dynamic capability which leads to the development of new operating capabilities (Brews and Hunt, 1999; Eisenhardt and Martin, 2000; Ramanujam and Venkatraman, 1987), as well as the strategy process literature (Hutzschenreuter and Kleindienst, 2006).

\section{Design and method}

This research addresses the following research problems in particular:

What is strategy implementation competence?

How is it different from the traditional strategy process view?

What are the antecedents of strategy implementation competence?

To this aim, after we conceptualize the strategy implementation competence, we develop a theoretical framework regarding its antecedents and its presumed relation with organizational performance. The research model developed in the study is depicted in Figure 1 below.



Figure 1: Research Model

We illustrate the application of our theoretical framework by a single cases study conducted in one of the leading firms in the tire industry in Turkey: Brisa Bridgestone Sabancı Lastik ve Ticaret A.Ş. Thus, the research is designed as a qualitative study. We conducted multiple company representatives and collected private company documents and publicly available company reports.

\section{Findings and discussion}

The investigation of the case company's strategy process in each of the three antecedents of strategy implementation competence resulted in fruitful insights about how organizations can improve their strategy implementation competence. Our interviews 
concluded that the case company actively attended all three antecedents. The scope of involvement in strategy formulation was broad and across levels. There were effective mechanisms in place to ensure alignment between and within units. The commitment to strategic drivers was established via personal and department level systems. The case company set an excellent case for demonstrating the developed theoretical framework.

\section{Conclusion, recommendations, and limitations}

The single case study illustrated the use of the theoretical model. This research contributes to strategy process research by providing a novel perspective that complements the traditional paradigm, particularly when strategy formulation is blurred by uncertainty, complexity, ambiguity, and volatility. A worm-eye view approach may complement the bird-eye view approach under such circumstances, acknowledging that the bird-eye view approach can set useful benchmarks and learning opportunities for the organization. Finally, we discussed several potential areas for improvement for the case company and presented recommendations for practitioners.

The limitations of this work include its exploratory approach, its focus on a single organization for demonstration purposes, and not associating strategy implementation competence with performance in this single case study. Future research can study multiple organizations, establish a measure to capture strategy implementation competence and the conditions under which this competence is associated with organizational performance. 


\section{Giriş}

Organizasyonların yüksek performans göstermelerinde ve hayatta kalmalarında kurumsal stratejilerin merkezi bir rolü vardır (Porter, 1997, 2008). Yunanca 'strategia' (kumandanın sanatı) kelimesinden türemiş olan strateji (Grant, 2016: 11), organizasyon bilimlerinde kurumların uzun dönem hedeflerinin ve bu hedeflere nasıl ulaşılacağının belirlenmesini içeren merkezi, dışa dönük ve bütünleşik bir kavram olarak tanımlanır (Hambrick ve Fredecikson, 2005: 52). Stratejinin amacı, pazarda sürdürülebilir rekabet avantajı yaratmaktır. Sürdürülebilir rekabet avantajı, firmanın müşterilerine sunduğu değeri rakiplerine göre daha kârlı şekilde yaratabilmesini sağlayan temelleri ifade etmektedir (Grant, 2016: 23). Dolayısıyla, sürdürülebilir rekabet avantajı ve bu avantajı oluşturan strateji, firma performansının en önemli belirleyicilerindendir. Ancak bir strateji ne kadar iyi tasarlanmış olursa olsun, etkin bir şekilde uygulanmazsa kurumun performansina olumlu bir katkıda bulunmaz (Noble, 1999: 119).

Stratejilerin tasarlanması ve uygulanması, kurumsal strateji süreçlerinin iki esas kısmıdır (Hutzschenreuter ve Kleindienst, 2006; Grant, 2016). Üst yöneticiler genellikle stratejilerin tasarlanmasına yüksek özen gösterirler; kurumlarını müreffeh bir geleceğe götürecek stratejik planların tasarlanabilmesi için otellerde hafta sonu tasarım çalıştayları yaparlar, kapsamlı pazar araştırmaları yaptırırlar ve danışmanlık şirketlerinin pahalı hizmetlerinden faydalanırlar (Noble, 1999). Ancak çoğu zaman, stratejik planlar beklendiği gibi gerçekleşmez ve hedeflere erişilemez (Hrebiniak, 2006). Bu durum yoğunlukla firmanın kontrolü dışındaki etmenlere atfedilir; bir rakip hiç beklenmedik çok başarılı bir ürün pazara sürmüştür, müşteri istekleri öngörülemez bir şekilde değişmiştir ya da talep bilinmez bir sebeple daralmıştır (Jordan ve Audia, 2012; Sedikides ve Gregg, 2008).

Halbuki çevrenin öngörülmezliğinin ötesinde, stratejik planların gerçekleşmemesinin altında yatan önemli bir etmen ise, firmaların tasarladıkları stratejileri uygulayabilme yetkinliklerini göz ardı etmeleridir (Kotter, 1995; Lee ve Puranam, 2016). Araştırmalar organizasyonlarda alınan stratejik kararların yüzde elliden fazlasının uygulama safhasında başarısız olduğunu göstermektedir (Nutt, 1999: 76). Strateji süreçleri üzerine yapılan araştırmalar ise, strateji uygulama yetkinliği yüksek olan firmaların, formüle edilen stratejiler optimal stratejilerden uzak olsa bile daha üstün performans gösterdiklerini bulmuştur (Lee ve Puranam, 2016: 1541). Yani alınan stratejik kararlar düşük kalitede dahi olsa, stratejilerin mükemmel bir şekilde hayata geçirilmesine yönelik amansız bir çaba gösteren şirketler yüksek performans göstermektedirler. Bu nedenle, strateji uygulama yetkinliğii, stratejilerin kurumsal performansa dönüşmesinde merkezi bir role sahiptir.

$\mathrm{Bu}$ çalışmada, strateji uygulama yetkinliği, bir organizasyonun eylemlerinin stratejik niyetleri ile örtüşme derecesi olarak tanımlanmaktadır. Formüle edilen stratejilerin temelinde de stratejik niyetler yatmaktadır, dolayısıyla formüle edilen stratejilerin kesin bir netlikte uygulanmasının eylemler ile stratejik niyetler arasında örtüşme yaratacağı düşünülebilir (Noble, 1999). Ancak, bu önerme sadece doğru stratejilerin önceden bilinebildiği varsayımı altında geçerlidir. Değişkenlik, belirsizlik, karmaşıklık ve muğlaklık ile şekillenen günümüz pazarlarında, bilişsel olarak sınırlı ve akılcılığı kısıtlı (boundedly rational) yöneticilerin tartışmasız biçimde doğru stratejileri belirlemeleri çok zordur (March ve Simon, 1958). Formüle edilen her strateji, yapıldığı andaki nesnel doğruya yakın da olsa bile, zaman içinde değişken, belirsiz, karmaşık ve bilinmez çevrenin şartları açığa çıktıkça geçerliliğini yitirebilir (Lee ve Puranam, 2016). Dolayısıyla, bu çevresel koşullar altında, formüle edilen stratejilerin kesinliğini arttırarak nesnel doğruya yaklaşma çabası her zaman faydalı olmayabilir. Bunun yerine, kurumlar strateji uygulama yetkinliklerini arttırarak, stratejilerin kurum içi tüm çalışanların katkısıyla hayata geçirilmesi esnasındaki stratejik niyetlerle uyumunu sağlamaları daha önemlidir. Formüle edilen stratejinin en iyi strateji olduğu garanti edilemeyeceğine göre, stratejilerin uygulanması esnasındaki stratejik niyetlere bağlı keşfedilen yeni yollar, kurumun öngörülemez çevreye uyum sağlaması açısından yüksek önem arz eder.

Strateji uygulama yetkinliği organizasyon performansı için yüksek önem arz etmesine rağmen, bu kavram yeterince net tanımlanmamış ve geleneksel strateji süreci yaklaşımından farkları ortaya konulmamıştır. Bu çalışma, organizasyonların strateji uygulama yetkinliklerini nasıl geliştirdikleri ile ilgili bir teorik çerçeve geliştirmeyi ve bu çerçevenin uygulamasının bir ampirik vaka çalışması ile göstermeyi amaçlamaktadır. Çalışmanın araştırma sorusu, strateji uygulama yetkinliğinin öncüllerinin neler olduğunun belirlenmesidir.

Bu kapsamda, öncelikle strateji uygulama yetkinliği kavramı tanımlanacak ve bu yaklaşımın geleneksel strateji süreci yaklaşımından farkları vurgulanacaktır. Sonrasında, strateji uygulama yetkinliğinin öncülleri ile ilgili bir teorik çerçeve geliştirilecek ve bu çerçeve lastik sektöründe faaliyet gösteren uluslararası bir firma olan Brisa Bridgestone Sabancı Lastik ve Ticaret A.Ş'nin strateji süreci ile ilgili bir 
vaka analizinde tatbik edilecektir. Çalışma, vaka analizi ile ilgili bulgular ve bulguların akademik katkılarının tartışması ile son bulacaktır.

\section{Literatür taraması ve teorik çerçeve}

\section{Strateji uygulama yetkinliği}

Strateji uygulama yetkinliği, eylemler ile stratejik niyetlerin uyumuna doğrudan vurgu yapması ile geleneksel strateji süreci görüşüne alternatif bir yaklaşım olarak ortaya çıkmaktadır. Bu bölümde, strateji uygulama yetkinliği görüşü, mevcut literatürdeki geleneksel strateji süreci görüşü ile kıyaslanarak açıklanmaktadır.

Stratejiler, detaylı eylem planları olmaktan ziyade kurumun yönünü gösteren ve stratejik niyetler doğrultusunda kurumun ulaşması beklenen gelecek durumu ile ilgili yol göstericilerdir (Amason, 1996: 128). Geleneksel strateji literatürü, strateji formülasyonunu üst yönetimin rolü olarak görürken, stratejilerin uygulanmasını ise orta ve alt kademe yöneticiler ile çalışanlara bırakmaktadır (Noble, 1999; Quinn, 1980). Ancak, 'düşünenler' (mind) ile 'yapanlar' (body) arasındaki bu Dekartçı ikilik (Cartesian mind-body duality) modern strateji literatürünce oldukça eleştirilmiştir. Orta düzey yöneticiler, operasyon yöneticileri ve astları sadece üst yönetim tarafından geliştirilen stratejileri uygulamakla sorumlu, pasif ve mekanik aracılar değildirler. Her ne kadar kurumsal performanstan, yani strateji süreçlerinin nihai başarısından üst yönetim sorumlu olsa da hiyerarşinin diğer kademelerindeki çalışanların stratejilerin uygulanmasının ötesinde stratejilerin oluşturulmasında da görevleri vardır (Floyd ve Lane, 2000: 154). Bu bağlamda, strateji uygulama yetkinliği bakış açısı, yukarıdan aşağıya dayatılan stratejilerin kalitesine eleştirel yaklaşır ve aşağıdan yukarı uygulama süreci esnasında keşfedilen stratejilere değer atfeder.

Strateji uygulama yetkinliği görüşüne göre, üstün performansa giden yol, firmanın kendisini içinde bulduğu ortamla tutarlı olan bir stratejinin uygun kurum içi düzenlemeler yoluyla uygulanmasında yatmaktadır. Bu görüşte, strateji tasarlama süreci, stratejik niyetlerin netleştirildiği, stratejik önceliklerin belirlendiği, kurum çalışanlarının hareket alanının genel sınırlarının çizildiği, sonrasında ise geniş katılım ile stratejik niyetler/öncelikler doğrultusunda tasarlanan gelecek durumunun projelendirilmesini içeren bir süreçtir. Yani strateji uygulama yetkinliği perspektifi, strateji belirleme sürecinin kuş bakışı (bird's eye view) yaklaşımının çizdiği çerçeve içinde, strateji uygulama süreci esnasında kurtçuk bakışı (worm's eye view) ile gerçeğe daha yakından temas eden stratejilerin belirlenmesini (önceden belirlenen stratejilerin revize edilmesini) ön planda tutar.

Strateji süreçlerine klasik bakış açısı statik ve ardışık (sequential) bir yaklaşım sergiler: stratejiler önce tasarlanır, sonra uygulanır (Hutzschenreuter ve Kleindienst, 2006). Strateji uygulama yetkinliği bakış açısı ise strateji süreçlerine dinamik ve yinelemeli (iterative) bir yaklaşım sergiler: stratejiler tasarlanır, uygulanırken stratejik niyetler doğrultusunda yeniden tasarlanarak hayata geçirilir (Şekil 1).

Klasik bakış açısı, durağan, belirli, basit ve kesin bilinir çevresel koşullarda, nesnel olarak optimal olan stratejiler formüle edilebildiğinde kurumsal başarı getirir (Mintzberg, 1973). Bu bakış açısı, belirlenen stratejilerin hiç sapma olmaksızın mükemmel olarak uygulanmasını hedefler ve kurumsal düzenlemeleri ve kontrol sistemlerini bu anlayış etrafında kurar (Hart ve Banbury, 1994). Ancak, çevre nadiren durağan, belirli, basit ve nettir. Yani stratejik planlama nadir olarak yanılmazdır ve gerçek hayattaki belirsiz, yetersiz ve tam olmayan bilgiye dayanarak kararlar almanın zorluğuyla da sürekli olarak yüzleşmek zorundadır.

Strateji uygulama yetkinliği bakış açısı ise, strateji tasarım sürecinin öğretici ve yön çizici işlevini yadsımamakla birlikte, strateji tasarımını uygulama ile iç içe geçirerek firmalara yol gösterir. Hiçbir organizasyon tasarımı veya kontrol sistemi çalışan davranışını mutlak olarak kontrol edemez, her zaman eylem safhasında çalışanların takdir yetkisinin olması kaçınılmazdır (Wooldridge vd., 2008; Raes vd., 2011). Bu takdir yetisine, klasik bakış formüle edilen stratejilerin uygulanmasından bir sapma olarak bakarken (Hart, 1992), strateji uygulama yetkinliği bakış açısı bir zenginlik olarak bakar. Organizasyonun tüm kademelerindeki bu bağımsız takdir yetisi ile stratejik niyet doğrultusunda eylemler düzenlenir. Bu tıpkı hareket eden bir hedefi vurmak için, hedef hareket ettikçe anlık olarak yeniden nişan alınması ve tetiğe tam basılacak ana karar verilmesine benzer. 


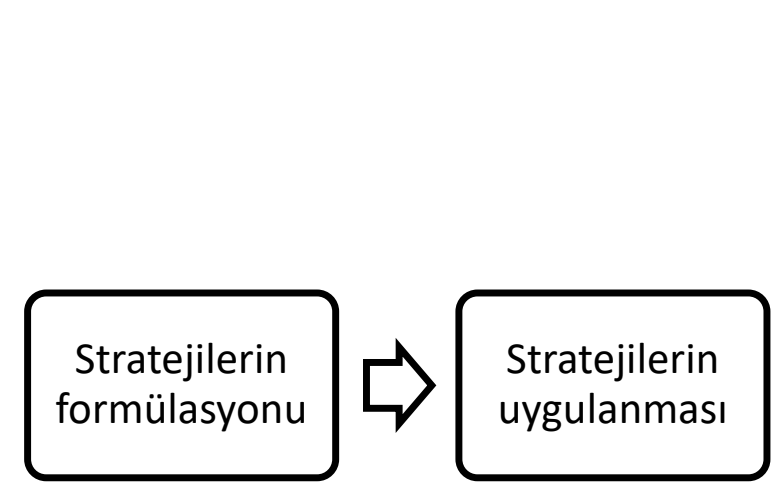

Geleneksel strateji süreci bakış açısı

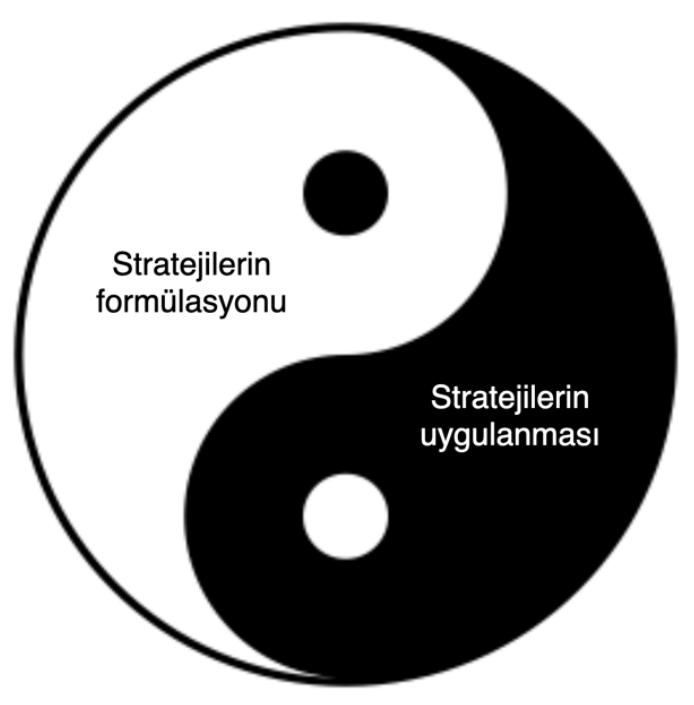

Strateji uygulama yetkinliği bakış açısı

Şekil 1: Geleneksel strateji süreci ve strateji uygulama yetkinliği bakış açıları

Kaynak: Şeklin geleneksel strateji süreci bakış açısı kısmı David ve David (2017) kaynağından alınmıştır. Strateji uygulama yetkinliği bakış açısı kısmı ise yazar tarafından üretilmiştir.

\section{Strateji uygulama yetkinliğinin öncülleri}

Modern stratejik yönetim literatürü, stratejilerin başarılı bir şekilde oluşturulması için geniş katılım ve farklı fikirlerin sürece katkıda bulunmasının, stratejilerin başarılı bir şekilde hayata geçirilmesi için ise kurum içindeki farklı kademelerdeki çalışanların stratejileri bilmesi, benimsemesi ve ortak bir anlayış etrafında hizalanmasının önemi vurgular (Lee ve Puranam, 2016; Raes vd., 2011; Wooldridge vd., 2008). Kurumun eylemlerinin stratejik niyetler ile örtüşmesini sağlayan, yani strateji uygulama yetkinliğini arttıran ise üç ana etmen sayılabilir: (i) geniş tabanlı stratejik katılım, (ii) stratejik uyum (hizalanma) ve (iii) stratejik bağlılık. Bu üç etmen, stratejilerin hayata geçirilmesi esnasında sadece üstün bir çaba gösterilmesini değil aynı zamanda bu çabanın stratejilerin arka planında yatan niyetlerle de uyumlu olmasını sağlar. Dolayısıyla, Şekil 2'de de gösterildiği üzere stratejik katılım, uyum ve bağlılık strateji uygulama yetkinliğinin öncüllerini oluşturmaktadırlar. Şekil 2'de kesikli ok ile strateji uygulama yetkinliğinin beklenen sonucu olan organizasyon performansı ile olan ilişkisi de resmedilmiştir. Ancak, bu ilişkinin ampirik olarak incelenmesi mevcut çalışmanın kapsamı dışında kalmaktadır; bu çalışma strateji uygulama yetkinliğinin öncüllerine odaklanmaktadır.

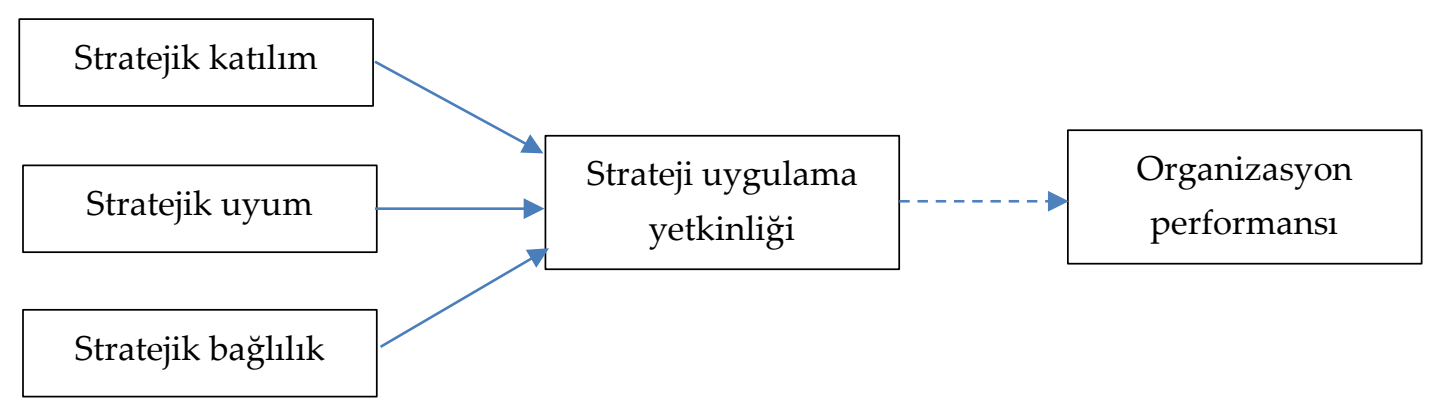

Şekil 2: Stratejik uygulama yetkinliğinin öncülleri

Kaynak: Yazar tarafından üretilmiştir.

\section{Stratejik katılım}

Stratejik katılım, strateji uygulama yetkinliğinin inşasında önemli bir rol üstlenir. Stratejik katılım, kurum içi farklı bölümler ve farklı hiyerarşik seviyelerden yönetici ve çalışanların strateji süreçlerine katkıda bulunmalarını ifade etmektedir (Wooldridge ve Floyd, 1990: 231). Geniş ve kapsayıcı bir stratejik katılımın ilk etkisi stratejilerin tasarlanmasında görülür. Tasarım esnasında geniş bir katılımın olmadığ1 strateji süreçleri nadir olarak kaliteli stratejik kararlar üretirler. Farklı birim ve çeşitli seviyelerdeki iç ve dış paydaşlar tarafından sunulan görüşler, alınan stratejik kararların kalitesini 
arttırır. Böylece, belirsizlik ve karmaşık ilişkiler ile şekillenen kurumsal çevre hakkında daha net ve gerçeğe daha yakın bir anlayış elde edilir (Floyd ve Wooldridge, 1992; Collier, Fishwick ve Floyd, 2004).

Stratejik katılımın, katılımcıların sundukları eşsiz görüşleri strateji tasarım sürecine dahil etmesinden daha önemli bir işlevi ise strateji uygulama yetkinliğine olan katkısıdır. Pratikte halen pek çok kuruluşta, stratejinin tasarımcıları ve uygulayıcıları farklıdır. Bu da üst yönetim tarafından tasarlanan stratejilerin, stratejilerin uygulayıcıları olarak görülen orta ve alt kademeler tarafından anlaşılması ve benimsenmesini zor kılar (Wooldridge vd., 2008). Stratejik katılım, tam da bu noktada geniş bir katılımcı tabanının kurum stratejilerinin altında yatan stratejik niyetleri öğrenmelerini, anlamalarını ve daha önemlisi uygulama süreci esnasında bu stratejik niyetler doğrultusunda fikir yürüterek eyleme geçebilmelerini sağlar. Bu örtülü katkı, belirlenen stratejilerin uygulanması esnasında kararların eleştirel bir tutum ile çevrenin gerçekliklerine uyumlu olup olmadığının kontrolü konusunda çalışanlara güven verir ve onları cesaretlendirir. Dolayısıyla, geniş tabanlı stratejik katılım organizasyonun eylemleri ile niyetlerini örtüştürmesiyle strateji uygulama yetkinliğine katkı yapar.

\section{Stratejik uyum}

Stratejik katılım farklı birim ve çeşitli seviyelerdeki çalışanların görüşlerinin strateji tasarımı esnasında temsil edilmesini sağlar; ama aynı zamanda geniş ve kapsamlı katılım, strateji süreçlerini politik davranışa, lobi faaliyetlerine ve etki taktiklerine açık hale getirir (Wooldridge ve Floyd, 1990). Bölümler arasındaki kaynak atamalarının ve dolayısıyla güç dağllımının belirlendiği strateji süreçlerinin, kurum içi entrikaların oynandığı politik bir arenaya dönüşmesi olumlu olarak değerlendirilmez (Guth ve MacMillan, 1986). Tam tersine, etkin stratejik katılımın bölümler arası çıkar ve güç çatışmalarını çözümlemesi beklenir. Bu ise ancak bölümler arası stratejik uyum (hizalanma) ile sağlanır. Bu nedenle, stratejik uyum, strateji uygulama yetkinliğinin diğer bir önemli öncülüdür.

Stratejik uyum, farklı bölümler arasında ya da aynı bölüm içinde çalışanlar arasında, stratejik öncelikler hakkında bir ortak anlayış oluşturularak fikir birliğine varılmasıdır (Tarakci, Ateş, Porck, van Knippenberg, Groenen ve de Haas, 2014: 1053). Stratejik uyum, stratejilerin uygulanmasi esnasindaki iletişimi, koordinasyonu ve iş birliğini teşvik eder (Bourgeouis, 1980; Colbert, Kristof-Brown, Bradley ve Barrick, 2008). Stratejik öncelikler hakkında çalışanlar arasındaki ortak anlayış, çalışanların günlük operasyonlarını doğru bir şekilde önceliklendirmelerine yardımcı olur ve bu sayede bölüm içinde farklı bireylerin ve farklı bölümlerin birbirlerinden bağımsız olarak gerçekleştirdiği eylemler, stratejik niyetlerle uyumlu olur (Ateş, Tarakci, Porck, van Knippenberg ve Groenen, 2020). Yani stratejik uyum ile birlikte stratejik uygulama yetkinliği artmış olur.

Her bir bölümün ve her kademedeki yöneticilerin, stratejik hedefleri birim ve bireysel hedeflere çevirebilmeleri için, stratejilerin altında yatan mantığı kavramaları gerekmektedir (Noble, 1999). Tüm seviyelerdeki yöneticiler ve çalışanlar, stratejik hedefleri, gündelik işleri gerçekleştirirken kendi gündelik operasyonel bağlamlarımda yorumlayabilmeli ve kendi çıkarımlarını yapabilmelidirler (Amason, 1996). Bu noktada, çalışanların stratejik planların ruhunu anlaması, stratejileri arkasında yatan nedenler ile uyumlu taktik ve operasyonel planlara çevrilmesi için hayatidir. Çalışanların ve yöneticilerin stratejileri sadece bilmesi yetmez, içerik olarak da anlaması ve doğru şekilde önceliklendirmesi gereklidir (Markoczy, 2001). Eğer orta düzey ve operasyonel yöneticiler ile üst yönetim arasında stratejik öncelikler konusunda ortak bir anlayış bulunmuyorsa, bu yöneticiler kendi bölümlerini yanlış yönlendirebilirler, stratejilerin uygulanmasına direnç gösterebilirler ve hatta sabote edebilirler (Guth ve MacMillan, 1986). Stratejik uyum, kurum çapında tüm yöneticilerin, kurumsal stratejileri günlük eylemler bağlamında yorumlayabilmelerini ve stratejilerin arkasındaki temel mantığ1 (stratejik niyeti) astlarına doğru şekilde iletebilmelerini sağlar (Tarakci vd., 2014).

Yüksek düzeyde stratejik uyum, stratejinin uygulanmasından sorumlu pek çok bağımsız aktörün, birbirlerinin eylemleriyle tutarlı ve stratejik niyetlerle uyumlu bir şekilde hareket etmesini sağlar. Bu ortak anlayış, öngörülemeyen sorunlar ortaya çıktığında, bu sorunların stratejinin arkasında yatan temel niyetlerle tutarlı bir şekilde çözülmesini sağlar. Stratejiye ilişkin ortak bir anlayış olmadığında ise, bölümler arası çatışmalar yaşanabilir ve bölüm çıkarlarını ön plana koyan alt optimizasyonlara odaklanılabilir (Beer ve Eisenstat, 2000). Bu olumsuzluklar da başarılı strateji uygulaması için gerekli olan organizasyon çapında stratejik niyetlerle tutarlı eylemlerin gerçekleştirmesini engeller. Yani strateji uygulama yetkinliğine zarar verir. Dolayısıyla, birimler arasındaki ve birim içi stratejik fikir birliği ve uyum, strateji uygulamasında anahtar bir rol oynar (Porck, van Knippenberg, Tarakci, Ateş, Groenen ve de Haas, 2020; Tarakci vd., 2014).

\section{Stratejik bağlılık}

Sadece stratejik katılım ve stratejik öncelikler üzerindeki fikir birliği stratejilerin etkin bir şekilde hayata geçirilmesini garanti etmez; tüm kurum kapsamında çalışanların stratejilere bağlılık da duyması 
gerekir. Stratejik bağlılık, çalışanların stratejilerin uygulanması için gösterecekleri gönüllü çaba, iş birliği ve destek olarak tanımlanır (Dooley, Fryxell ve Judge, 2000: 1239). Stratejik bağlllıkları yüksek olan çalışanlar, stratejilerin başarıyla gerçekleştirilmesi için taahhütlerde bulunurlar ve görev tanımlarındaki resmi vazifelerinin ötesinde inisiyatif alırlar (Ateş vd., 2020). Çalışanlar stratejiye bağlı olduklarında, çabalarının kurumsal stratejinin ayrılmaz bir parçası olduğunu kabul ederler. Sonuç olarak, diğer çalışanlar ve bölümler ile iş birliği içinde çalışırlar ve yalnızca kendi çıkarlarına hizmet eden davranışlara daha az meyilli hale gelirler. Böylelikle stratejik bağlılık, strateji hakkında olumlu bir tutum takınmanın ötesine geçer; çalışanların stratejiyi uygulamak için çaba sarf etme isteklerini ve duydukları sorumluluğu ifade eder (Korsgaard, Schweiger ve Sapienza, 1995: 61).

Çalışanlar kurumsal stratejiye bağllıı duymadığında ise, stratejinin kurumun ve/veya kendi bölümlerinin çıkarlarına hizmet edip etmediği konusunda şüphe duyarlar (Herold, Fedor, Caldwell ve Liu, 2008). Stratejik bağl1lığı düşük çalışanlar, yine de stratejileri bilebilir ve stratejiler üzerinde fikir birliğine de varmış olabilirler. Ancak, stratejilerin kurum için fayda göstereceğine olan inanç ve ikna olmuşlukları düşük olduğu için stratejilerin hayata geçirilmesi için çaba sarf etme istekleri düşüktür (Korsgaard vd., 1995).

Stratejik bağlılık çalışanların kuruma karşı duydukları sosyal aidiyet ile de yakından ilgilidir. Sosyal aidiyet teorisi, insanların kendilerini sosyal gruplara üyelikleri etrafında algıladıklarını söyler. Sosyal aidiyet, bireyin kimliği ile sosyal grup kimliğinin bütünleşmesi ve ortak bir biz anlayışı çıkması ile oluşur (Ashforth ve Mael, 1989). Bu bağlamda, stratejik bağlllık kurumsal aidiyeti de geliştirir. Çalışanlar kurumun hedeflerini kendi hedefleri olarak benimserler. Sosyal aidiyet, strateji uygulama yetkinliği için de işlevseldir: çalışanlar kurumun kimliğini kendi kimliklerinin bir uzantısı olarak gördükleri için, tasarlanan stratejileri körü körüne uygulamazlar ve stratejik niyetler çerçevesinde eleştirel olarak ele alırlar (Mael ve Ashforth, 2001). Böylelikle, her çalışan mevcut bağlam içerisinde mikro stratejik yenilenmelere yol açar ve kurumun çevreye adapte olabilme yeteneğini arttırır. Stratejik bağlllık, bu sebeplerle strateji uygulama yetkinliğinin önemli bir öncülü olarak ortaya çıar.

Özetle, strateji süreçlerine strateji uygulama yetkinliği bakış açısı, geleneksel bakış açısından şu konularda farklılaşır. Strateji formüle etme süreci strateji uygulama sürecinin içine yayılmıştır; yukarıdan aşağıya doğru belirlenen stratejiler uygulama esnasında revize edilir ve alttan üste yeni stratejiler ortaya çıkabilir. Strateji oluşturma sürecine geniş kapsamlı katılım sadece belirlenen stratejilerin kalitesini arttırmaz, aynı zamanda katılımcıların stratejilerin arkasında yatan niyetleri anlamalarını sağlar. Bu ortak anlayış, stratejilerin uygulanması esnasında hem stratejik uyumu (hizalanma) hem de stratejik bağlılığı teşvik eder. Katılım, uyum ve bağlılığın getirdiği strateji uygulama yetkinliği de tüm organizasyon çapında gösterilen eforun stratejik niyetler doğrultusunda olmasını sağlar. Öngörülemez çevresel koşullar zaman içinde çözümlendikçe, kurumdaki her bir birim ve çalışan stratejileri uyarlama ve yeni yollar keşfetme konusunda kendilerini sorumlu ve yetkin görürler.

Bir sonraki bölümde, strateji süreçlerine 'strateji uygulama yetkinliği' bakış açısı ve öncülleri Brisa'nın strateji süreçleri bağlamında bir vaka analizi olarak incelenmiştir.

\section{Yöntem}

\section{Vaka şirketinin tanıtımı}

Bu çalışmada, Brisa Bridgestone Sabancı Lastik Sanayi ve Ticaret A.Ş.'nin strateji süreçleri incelenmiştir. 1974 yılında Sabancı Holding ve ortakları tarafından kurulan Lassa markasının, 1988 yılında Bridgestone ile yaptığı bir ortak girişim (joint venture) ile kurulan Brisa, hem Türkiye lastik endüstrisinde lider konumda olan bir firmadır hem de dünyada 80'den fazla ülkede faaliyet gösteren küresel bir oyuncudur. Yakın zamanda sektörün geleceğine Aksaray'da akıllı bir fabrika kurarak önemli bir yatırım yapan Brisa'nın ciddi bir büyüme iştahı olduğu görülmektedir. Dolayısıyla, Brisa geleceği olabildiğince berrak olarak görmek istemektedir ve bu bilinçle tasarladıkları olgun bir strateji süreci bulunmaktadır.

Lastik endüstrisi ciddi bir dönüşüm içerisindedir; teknoloji, pazar koşulları ve müşteri beklentileri sürekli olarak değişmektedir. Küresel olarak faaliyet gösteren Brisa, dünya pazarlarındaki gelişmelerden etkilenen, dolayısıyla bu pazarları yakından takip eden bir firmadır. Brisa'nın aktif olduğu pazar, yerli ve yabancı rekabete açı ve çok dinamik bir pazardır. Brisa, bu pazarda sadece büyük bir üretici değil, aynı zamanda bayi ağıyla birlikte büyük bir perakendecidir. Önemli bir tamamlayıcı sektör olan otomotiv sektöründe ise sarsıcı teknolojik gelişmeler gözlenmektedir; hâkim olan standart yakıt teknolojisi yerini elektrik teknolojisine bırakmaktadır. 
Lastik giderek metalaşan bir ürün (commodity) halini almaktadır. Önceden sahip olunan lastik teknolojisi ve mühendislik becerileri sayesinde ürün performansındaki üstünlükler ile farklılaşmaya gidebilen Brisa, günümüzde pazarda bu farkın tek başına yeterli olmadığını gözlemlemektedir. Tüketici artık ürün performansının ötesinde değer beklemektedir. Üst sınıf ürünler ile bütçe ürünler arasındaki fark, ürün performansından ziyade ürünle birlikte sunulan toplam paket (total package) ile belirlenmektedir. Brisa'da da bu trend doğrultusunda, bir 'lastik sağlayıcısı' olmaktan bir 'mobilite (hareketlilik) çözümleri sağlayıcısı' (mobility solutions provider) olmaya evrilme yönünde zihni bir dönüşüm gözlemlenmiştir. Yani müşteriye sunulan nihaî değerin yeniden tanımlanmasıyla birlikte, sektördeki tüm rekabet dinamikleri değişmiştir. Bu koşullar altında Brisa'nın çevresi yüksek belirsizlik, değişkenlik, karmaşıklık ve muğlaklık ile karakterize olmaktadır. Brisa bu yeni ürün pazarında kendisini yeniden ve doğru olarak konumlandırma çabası içerisindedir. Brisa' nın stratejisi ve strateji süreçleri bu yeni konumlandırmada merkezi bir rol oynadığı için çok önemlidir.

\section{Tekli vaka analizi}

Sektör düzeyindeki gözlemlenemeyen farklılıkları elemek ve çalışmanın içsel geçerliliğini yüksek tutmak için tek bir sektöre odaklanılmıştır. Brisa strateji süreci, lastik endüstrisindeki dönüşüm ve Brisa'daki stratejik zihniyet değişimi dolayısıyla teorik olarak strateji uygulama yetkinliği konusuyla yakından ilgilidir ve araştırmacının mevcut ilişkileri sayesinde bir elverişlilik örneği olarak seçilmiştir (Gibbert, Ruigrok ve Wicki, 2008). Çalışmada geliştirilen stratejik uygulama yetkinliğinin öncüllerini içeren teorik model tekli vaka analizi yöntemi ile incelenmiştir. Bu yöntem, karmaşık kavramsal modellerin neden ve nasıl çalıştıklarının açıklanmasını kolaylaştıran kalitatif bir yaklaşım olduğu için çalışmanın amaçları için uygundur (Gummesson, 2000; Yin, 2009). Tekli vaka analizinde, kavramların bir organizasyon içindeki evrimi, birbirleriyle etkileşimi ve devinimi farklı paydaşların perspektifinden çalışılır (Gerring, 2006; Yin, 2009).

\section{Veri}

Vaka analizi için veriler Brisa yöneticileri ile yüz yüze ve çevrim içi toplantılarda yapılan mülakatlar ve şirket belgelerinin ve raporlarının incelenmesi ile 2020 yılı itibarıyle toplanmıştır. Brisa Genel Müdürünün de katıldığı başlangıç toplantısında strateji sürecinin genel planı aktarılmıştır. Sonrasında, strateji süreçlerinin tasarlanması ve yürütülmesinden sorumlu yönetici ve uzman çalışanlardan Pazarlama Mükemmelliği Müdürü, Kurumsal İletişim Müdürü, Yönetim Sistemleri Müdürü, Yalın İş Modeli Müdürü, İş Planlama Müdürü, Pazar Araştırma Uzmanı ve Kurumsal Marka ve İletişim Uzmanının katıldığı, altmış ile doksan dakika arasında değişen altı adet açık uçlu ve derinlemesine toplantı gerçekleştirilmiştir. Bu toplantılarda kurumun strateji sürecinin evrimi detaylıca çalıştırılmıştır ve açık uçlu mülakat yöntemi ile çalışma kapsamında incelenen dört kavram ile ilgili kapsamlı nitel veri toplanmıştır.

Stratejik katılım, stratejik uyum, stratejik bağl1lık ve strateji uygulama yetkinliği hakkında mülakatlarda sorulan sorular, literatürdeki önceki çalışmalar üzerine inşa edilerek geliştirilen tanımlara dayandırılarak belirlenmiştir. Katılımcılar ile kurumun strateji süreçleri hakkında mülakatlar gerçekleştirilmiştir. Stratejik katılım ile ilgili veriler, stratejilerin formüle edilmesi ve uygulanması esnasında farklı bölüm ve farklı hiyerarşik seviyelerden hangi yönetici ve çalışanların, hangi düzeyde ve nasıl katkılar yaptıkları sorgulanarak derlenmiştir. Stratejik uyum, kurumun stratejik öncelikleri hakkında kurum içindeki birimler içinde ve farklı birimler arasındaki ortak anlayış sorgulanarak incelenmiştir. Strateji oluşturma ve uygulama süreçleri içinde, stratejik uyumun artmasına yardımcı olan uygulamalar özellikle araştırılmışır. Stratejik bağlılık kavramı için ise, hem katılımcıların stratejik önceliklerin hayata geçmesi için sundukları gönüllü destekleri hem de bağlı ve ilişki içinde bulundukları diğer birim ve çalışanlar arasındaki destek ile ilgili sorular sorulmuştur. Benzer şekilde strateji uygulama yetkinliği, günden güne gerçekleştirilen eylemlerin stratejik öncelikler ile uyumu sorgulanarak elde edilmiştir.

Katılımcılar hem strateji sürecinin sonuçlarından sorumlu olmaları hem de bu süreçteki karar vericiler olmaları nedeniyle, bu konular hakkında kurum içindeki devinime yakından hakimdirler. Her toplantıda düzenli notlar tutulmuş, toplantı sonrası konuşulanlar temize çekilerek ve toplantıya katılanlarla paylaşılarak teyit alınmıştır. Mülakatlar sonucunda oluşturulan rapor ayrıca üst yönetime sunulmuş ve bir üst seviyede de kontrolü sağlanmıştır. Bu şekilde, edinilen nitel verilerin güvenilirliği, temsil ediciliği ve geçerliliğinin yüksek olması sağlanmıştır (Gerring, 2006; Yin, 2009). Analize geçilmeden önce, toplanan nitel veri yukarıda bahsedilen sorular ve kavramların teorik tanımları göz önünde bulundurularak kodlanmıştır. İlgili alıntılar bir araya getirilerek, her bir kavram hakkındaki kurum çapından görüşler bir araya getirilmiştir. 


\section{Güvenilirlik}

Araştırma modelindeki kavramların kurum içinde zaman içindeki değişimi, kurumun strateji süreçleri ile yakından ilgili üst düzey yöneticiler ve stratejik planlamada sorumlu deneyimli uzmanlar tarafından değerlendirilmiştir. Katılımclar sürecin başından beri şirkette çalışan ve strateji süreçleri ile ilgili karar alma yetkileri olan üst düzey yönetici ve uzman düzeyindeki kişilerdir; bu nedenle sağlanan yanıtların temsil ediciliği ve güvenilirliği yüksektir (Gerring, 2006). Ayrıca, katılımcılar ile yapılan mülakatlarda verdikleri cevapların birbirine yakınsadığı ve katılımcıların sağladığı bilgilerin doygunluğa ulaştığı gözlemlenmiştir. Toplanan bilgilerdeki yakınsama ve doygunluk da toplanan verinin güvenilirliğine işaret etmektedir (Yin, 2009). Veri toplama sürecindeki, katılımcılar tarafından sunulan bilgiler arasındaki tespit edilen çelişkili görülen kısımlar, katılımcılarla tekrar görüşülerek netleştirilmiş ve bu konular üzerinden ortak bir anlayış oluşana dek sürdürülmüştür. Aynı zamanda, mülakatlarda açık uçlu sorular ile toplanan veriler, şirket dokümanları ile karşılaştırılarak da karşılıklı kontrol sağlanmıştır. Veriler üzerinde konsensüs oluşturulması ve toplanan verilerin çapraz kontrolü de analiz girdilerinin güvenilirliğini arttırmaktadır (Grant, 2016).

\section{Vaka analizi: Brisa strateji süreci}

Bu bölümde, Brisa'nın strateji süreci detaylı bir şekilde incelenmeden önce, Brisa'nın kurumsal stratejileri (strateji içeriği) aktarılmaktadır. Strateji formülasyonu sonucunda belirlenen bu içerik, strateji uygulama sürecine temel bir girdi teşkil etmesi bakımından önemlidir. Daha sonra, kapsamlı olarak tariflenen Brisa strateji süreci, 'stratejik uygulama yetkinliği' bakış açısı ile, stratejik katılım, stratejik uyum ve stratejik bağllık başlıkları altında değerlendirilmektedir.

\section{Brisa'nın strateji içeriği}

Brisa'nın kurumsal stratejisinin içeriği, her yıl eklemeler ve çıkarmalar yapılarak revize edilen bir kavramlar hiyerarşisi ile ifade edilmektedir. Bu hiyerarşinin temel kavramları Şekil 3'te gösterilmiştir.

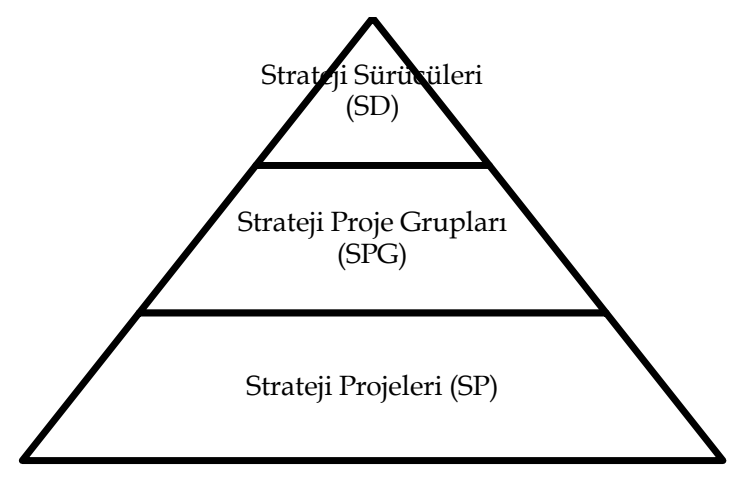

Şekil 3: Brisa' nın stratejilerini belirlemekte kullandığı temel kavramlar

Kaynak: Yazar tarafından üretilmiştir.

Bu hiyerarşinin en üst seviyesinde, aynı zamanda bir 'yelkenli gemi' analojisi ile görselleştirilen, stratejik sürücüler/stratejik gerçekleştiriciler (strategic drivers, SD) bulunmaktadır. Stratejik sürücüler Brisa'nın stratejik odağına rehberlik eden itici güçlerdir. Her bir stratejik sürücü, yelkenli geminin anlamlı bir öğesini oluşturmaktadır. Şekil $4^{\prime}$ te gösterilen mevcut stratejik planda, akıllı kültür (SD1) yelkenlinin rüzgâr1, operasyon mükemmeliyeti (SD2) ve Türkiye pazarındaki tartışmasız liderlik (SD3) yelkenlinin gövdesi, nakit yönetimi (SD4), ihracatta büyüme (SD5) ve toplam mobilite yönetimi (SD6) ise yelkenleri temsil etmektedirler.

Bu analojide, yelkenli geminin gövdesi (SD2 ve SD3) Brisa'nın temel yapıtaşlarını, yani olmazsa olmaz stratejik önceliklerini ifade etmektedir. Gövdedeki stratejik sürücüler çok sık değişmezler. Yelkenli geminin yelkenleri (SD4, SD5 ve SD6) stratejik inisiyatifleri, yani mutlaka kazanılması gereken mücadeleleri temsil etmektedir. Yelkendeki stratejik sürücülerin değişip değişmeyeceği her yıl takip edilir. Bu inisiyatiflerin stratejik görülmesinin nedeni, Brisa'nın önündeki 3-5 yılına etkilerinin büyük olmasıdır. Yelkenin gövdeden farkı, yelkendeki her bir stratejik sürücünün gövdedeki stratejik sürücülerin alt bileşenleri olabilmesidir. Yani yelkendeki stratejik sürücüler firmayı başarılı bir geleceğe taşıyacak ana projeler olarak görülebilir. Yelkenli gemi analojisinde, rüzgâr (SD1) ise yelkenin arkasındaki itici güç olan kurum kültürünün kritik bileşenlerini temsil etmektedir. Bu stratejik sürücüler Sabancı ve Bridgestone'un kurumsal değerler havuzu içinden anahtar olanlar seçilerek belirlenir. Çok sık değişmezler ama sürekli gelişmeleri takip edilir. Yani yelkenlinin gövdesi ve rüzgârı genellikle daha sabit olarak görülürken, gövde ve rüzgâr içinden çıkan yelken kısmındaki stratejik sürücülere 2-3 sene kadar özel önem atfedilir. Örnek olarak, 2018-2021 arasında nakit yönetimi, 2018- 
2021 arasında ihracatta büyüme, 2019'da Aksaray fabrikası, 2020'de E2E öğrenme, 2021'de mobilite çözümleri ön plana çıkmıştır.

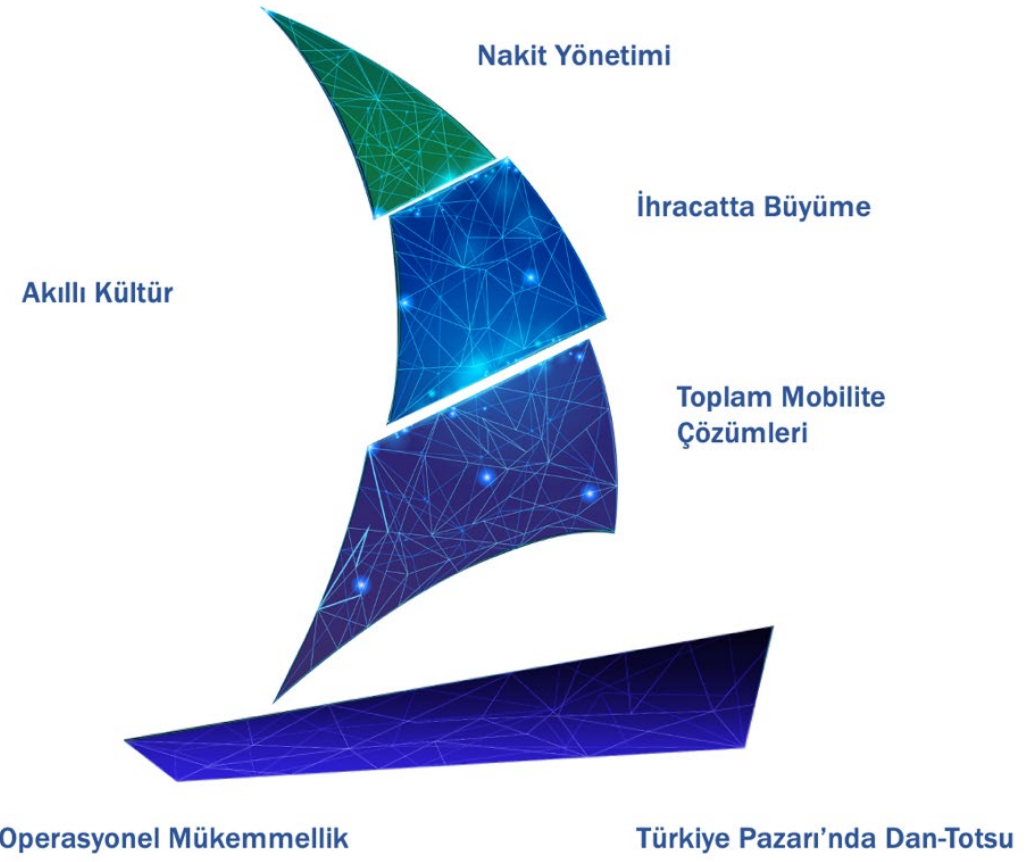

Şekil 4: Brisa'nın stratejik sürücülerini gösteren yelkenli gemi analojisi

Kaynak: Brisa strateji belgelerinden alınmıştır.

Yelkenli gemi analojisi, kurumu çevreleyen yüksek belirsizlik, değişkenlik, karmaşıklık ve muğlaklığa karşı kurumun adaptasyon göstermesini sağlayacak stratejik yenilenmenin anahtarı olarak kabul edilmektedir. Aynı zamanda, bu analoji Brisa'nın stratejinin temel öğelerini ve hedefleri paydaşlara duyurmakta işlevsel bir rol oynamaktadır: bayilerle yapılan çalıştaylarda Brisa'nın ne yöne gitmek istediği bu analoji ile aktarılmakta, basın ve yatırımcılarla paylaşılmakta ve ödül alan strateji projelerinin iletişiminde de kullanılmaktadır.

Hiyerarşinin ikinci ve üçüncü katmanlarında, stratejik sürücüler altında organize olan stratejik proje grupları (SPG) ve SPG'ler altındaki stratejik projeler (SP) bulunmaktadır. SPG'ler şirket iş planı ve stratejisi doğrultusunda tasarlanan ve 3 yıl içinde sonuçlarını vermesi öngörülen tematik proje kümelerini ifade eder. SP'ler ise SPG hedeflerine hizmet eden 2 ile 5 ay arasında pilot aşaması tamamlanacak şekilde tasarlanan somut projelerdir. Projeler, proje ekibini proje müşterilerine hizlı değer yaratmaya odaklanmaları ve geribildirim döngülerinin daha sık olmasının sağlanması için küçük parçalara ayrılarak (i.e., concept, pilot, test, scale-up) tanımlanmaktadırlar. Bu projeler, çevrimiçi olarak Brisa'nın inovasyon ve proje portalinde (Brisa innovation and projects portal, BIPP), fikir geliştirme, konsept tanımı, prototip geliştirme, geliştirme ve ticarileştirme adımlarından oluşan 'stage gate' metodolojisi ile takip edilirler.

SP’ler finansal değer ve etki ettikleri kişi sayısına göre ise 3 kategoriye ayrılırlar: (i) Dönüşümcü Liderlik Takımı projeleri (TLT projeleri) üç yıl içinde Faiz Amortisman ve vergi Öncesi Karı - FAVÖK- (Earnings Before Interest, Tax, Depreciation and Amortization -EBITDA-) 10 Milyon \$'dan büyük olan veya 50 'den fazla kişiyi etkileyecek projelerdir, (ii) A tipi projeler FAVÖK'ü 5-10 Milyon \$ arasında olan veya 25-50 kişiyi etkileyecek projelerdir, (iii) B tipi projeler ise FAVÖK'ü 5 Milyon \$'dan küçük olan veya $25^{\prime}$ ten az kişiyi etkileyecek projelerdir. Brisa'nın kurumsal stratejisi, yelkenli gemide gösterilen 6 stratejik sürücünün altında toplamda 25'e yakın SPG ve bu SPG'lerin altında 100'e yakın SP ile tanımlanmıştır.

\section{Brisa'nın strateji süreci}

Brisa strateji süreci her yıl mayıs ayında başlayan ve aralık ayı sonunda sonuçlanan bir maratondur. Bu maraton, Şekil 5'te resmedilen 'Brisa İş Planlama Rotası' adı verilen şemaya göre koşulur. 


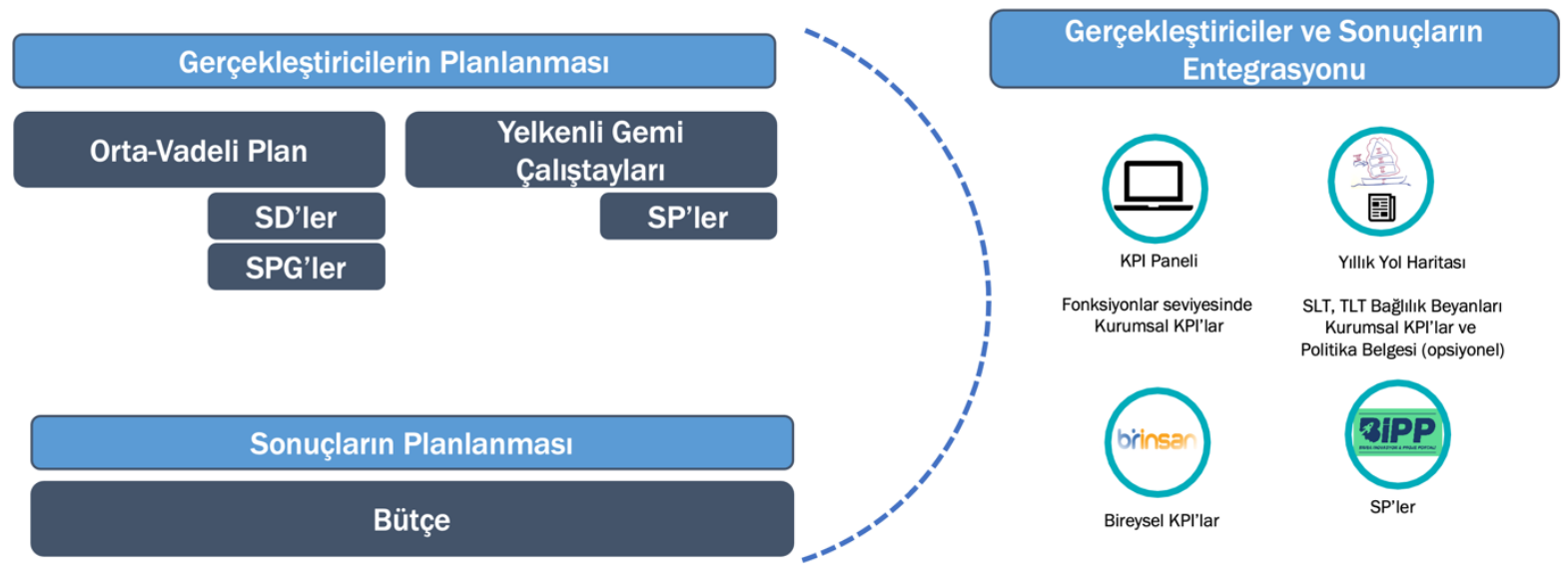

Şekil 5: Brisa iş planlama rotası

Kaynak: Brisa strateji belgelerinden alınmıştır.

Brisa'nın strateji tasarım süreci üç ana safhada ele alınabilir:

(i) gerçekleştiricilerin/sürücülerin planlanması,

(ii) sonuçların planlaması, ve

(iii) gerçekleştiriciler ve sonuçların bütünleştirilmesi.

Bu üç safhada, tüm geleneksel strateji süreçlerinde olduğu gibi, önce stratejik hedefler belirlenmekte, sonra ise bu hedeflere erişilmesi için atılması gereken adımlar tasarlanmaktadır. İlk iki safha birbirine paralel olarak gerçekleştirilir. Sonrasında ise sonuçlar ve gerçekleştiriciler entegre edilerek, yıllık yol haritası çalışılır ve kurum içi sistemlere gerekli girişler yapılır. Bu aşamada, KPI (Key Performance Indicators, Kilit Performans Göstergeleri) Paneli fonksiyonlar için belirlenen stratejik hedeflerin takip edildiği sistemi, BIPP (Brisa İnovasyon ve Proje Portalı) Stratejik Projelerin takip edildiği platformu ve BRINSAN (Brisa İnsan Kaynakları Platformu) bireysel KPI'ların takip edildiği sistemi göstermektedir. $\mathrm{Bu}$ sistemler stratejilerin uygulanmasını yakından takip eden kurumsal bilgi sistemleridirler.

Sürecin adımlarını detaylandırmadan önce, süreçte rol alan iki önemli yönetici grubunu tanımlamak yerinde olur. (i) Kıdemli Liderlik Takımı (senior leadership team, SLT). Brisa'nın yıllık stratejik hedeflerinin gerçekleştirilmesi ve gelecek 3 yıllık sürdürülebilir büyümesinin şekillendirilmesi için kurulmuş bir takımdır. (ii) Dönüşümcü Liderlik Takımı (transformational leadership, TLT) ise gelecek iş modellerini, çalışma şeklini ve kültürünü şekillendirerek Brisa'nın dönüşümünü tasarlamak ve yönetmek amacıyla kurulmuştur. Her iki yönetici grubu da direktör ve üstü seviyedeki yöneticilerden kurulmuştur.

\section{Gerçekleştiricilerin/sürü̈cülerin planlanması}

İş planlama rotasının ilk safhası 'gerçekleştiricilerin/sürücülerin planlanması' adımıdır. Strateji tasarımının bu ilk adımında, Mayıs ayından Haziran ayı başına kadar, 'Strateji Dokümanı'nı ortaya çıkartmak için, üç yıllık $(X+3)$ bir orta vadeli planlama yapılır. Daha önce beş yıllık $(X+5)$ olarak yapılan bu çalışma, çevre koşullarının belirsizliği, karmaşıklığı ve değişim hızı sebebiyle üç yıla indirilmiştir. Bu kapsamda sırasıyla aşağıdaki çalışmalar yapılır.

Değerlendirme: Orta vadeli planlamanın ilk adımı, orta ve üst düzey yöneticilere yapılan bir anket çalışmasıdır. Ankette, yelkenli gemi modelindeki stratejik sürücüler (SD'ler) ve SD'lerin altındaki SPG'ler önem ve performanslarına göre değerlendirilir (Anket soruları: (i) aşağıda listelenen mevcut stratejik sürücülerin performansını genel olarak nasıl değerlendirirsiniz? (ii) hangi stratejik sürücüleri bir sonraki dönemde de tutmalıyız? (iii) aşağıdaki strateji proje gruplarının önemini nasıl değerlendirirsiniz? (iv) aşağıdaki strateji proje gruplarının performansını genel olarak nasıl değerlendirişiniz?). Aynı zamanda, yeni yılda SD ve SPG'lerde yapılması gereken revizyonlar ile ilgili katılımcıların görüşleri alınır. Yeni SD ve SPG önerileri toplanır. SD ve SPG'lerde başarıyla gerçekleştirilerek vadesini tamamlayan sürücü ve proje grupları da sorgulanır.

Yaklaşık 60 yöneticinin katıldığı değerlendirme anketinin sonuçları hem bütünsel olarak hem de icra kademesi ile orta kademe yöneticilerin cevapları seviyesinde detaylıca çalışılır. İcra kademesi ve orta kademe arasındaki değerlendirmelerde birbirinden ayrışan ve birbiriyle uyumlu olan noktalar dikkatle incelenir. Bu sonuçlar kıdemli liderlik takımı ve dönüşümcü liderlik takımı ile de değerlendirilir.

Anket sonuçları 1şığında, yelkenli gemi modeli üzerinde bir diyalog başlar. Bir SD taahhüdünü tamamladıysa, bir diğer SD altında bir SPG olarak hayatına devam edebilir veya yelkenli gemi 
modelinden çıkartılabilir. Giderek büyüyen bir SPG ise bir SD'ye dönüşebilir. Önemini yitiren veya başarıyla gerçekleştirilen bir SPG modelden çıkartılabilir. Genel olarak, SD'ler ile belirlenen stratejik öncelikler daha az değişmektedir. SD içeriğinde netleştirmeler ve küçük revizyonlar daha sıklıkla görülür. Örnek olarak, 'üretim mükemmelliği' üzerine olan öncelik, tedarik zincirlerinin -özellikle Covid-19 salgını esnasında daha fazla hissettiğimiz- kritik önem arz etmesi nedeniyle 'operasyonel mükemmellik' olarak daha kapsamlı hale getirilmiştir. Yelkenli gemi modeli üzerindeki bu diyalog sırasında, aktif bir stratejik uyum ve ortak anlayış arayışı vardır.

Stratejik analizler: İlk olarak kapsamlı bir 'gösterge analizi' yapılır. Makro ekonomik ve hareketliliğe (mobility) etki eden göstergeler, sonraki 3 yıl için çalışılır ve senaryolar tariflenir. Daha sonra 'trend analizi' çalışması yapılır. Mega trendlerin tüketici tercihleri ve hareketlilik trendleri üzerindeki etkisi analiz edilerek Brisa stratejisine ve finansallarına etkisi tahmin edilir. Sonrasında 'pazar görünümü' analiz edilir. Pazarın genel durumu ve rekabet koşulları Brisa' nın alacağı konumu netleştirmek için çalışılır. Belirlenen konum için atılması gereken adımlar ilk olarak sürecin bu aşamasında konuşulmaya başlar. Pazarın genel durumu analiz edilirken Porter'ın 5 gücü ve SWOT gibi araçlardan faydalanılır. Son olarak 'senaryo planlama' analizi ile 4 farklı olası endüstri senaryosu çalışılır. Her bir senaryonun pazar ve Brisa üzerindeki etkileri sorgulanır. En olası senaryo üzerinden strateji çalışmalarına devam edilir, ancak diğer senaryolar için de kritik başarı faktörleri netleştirilir. Tüm bu analizlerde veri odaklı bir yaklaşım izlenir ve çok çeşitli analitik veri bilimi yöntemleri kullanılır.

Strateji ve kilit gerçekleştiriciler: Bu aşamada, makro-ekonomi trendleri, hareketlilik trendleri ve pazar şartları ile birlikte Brisa vizyonu, misyonu, yetkinlikleri ve değerleri göz önünde bulundurularak stratejik yön ve öncelikler netleştirilir. Sonuç olarak, bir sonraki dönemin SD'leri bu noktada nihai hale getirilir (korunur, yeniden konumlandırılır veya değiştirilir). Aynı zamanda SD'lere hizmet edecek SPG'ler ile ilgili hedefler ve kritik adımlar derlenir.

\section{Sonuçların planlanması}

İş planlama rotasının ikinci safhası 'sonuçların planlanması' (bütçe planlaması) adımıdır. Orta vadeli planlama göz önünde bulundurularak, temmuz ile eylül ayları arasında yapılan bütçe çalışmaları ile plan somut rakamlara indirgenir. Üç yıllık bütçe ve finansman çalışmasının ilk yılı aylık bazda, sonraki iki yılı ise yıllık bazda yapılır.

Bütçe çalışmalarının önemli girdilerinden biri pazar tahminleridir. Bu nedenle, bu adıma kapsamlı bir 'pazar tahminleme çalışması' ile başlanır. Son 15 yıldaki lastik satışları, makro-ekonomik ve lastik pazarı verileri ile kurulan ve 150 'den fazla indikatör içeren regresyon modelleri aracılı̆̆ıyla 3 yıllık pazar tahminleri ve pazarın gerçekleşmesi beklenen alan (pazarın maksimum ve minimum ulaşacağı satış adetleri) çalışılır. Bu tahminler için, GDP, enflasyon, kur değişimleri, araç satışları, araç parkı, nüfus, akaryakıt tüketimi, otoyol uzunlukları, araç üretimi, araç üreticilerinin kapasite kullanım oranları, trafik yoğunluğu gibi değişkenlerin son 15 yıllık verilerinin olduğu bir veri tabanından faydalanılır.

Pazar tahminlerinden çıkan öngörü ışığında bütçe çalışılır. Bütçe çalışması ile Brisa'nın 3 yıllık finansal hedefleri netleştirilir, hedef satış rakamları belirlenir ve bu rakamlar stratejilerle eşleştirilir. Bütçeleme dönemi içerisinde, yöneticiler belirlenen stratejiler kapsamında kendi birimlerinin pozisyonlarını kararlaştırırlar ve farklı birimler arası yoğun bir etkileşim olur.

\section{Gerçekleştiricilerle sonuçların entegrasyonu}

İş planlama rotasının üçüncü safhası 'gerçekleştiricilerle sonuçların entegrasyonu' adımıdır. Bütçe çalışmaları ile netleştirilen finansal hedeflerden sonra, 'Yol Planı Taahhüt Beyanı' (commitment statement) adı verilen bir kitapçık çalışılır. Bu çalışmanın amacı, Brisa yöneticileri arasında sistemler, planlar ve hedeflenen sonuçlar hakkında netlik ve uyum sağlamaktır. Bu kitapçıkta, Brisa'nın iş planlama sistemleri, $\mathrm{X}+1$ için sağlayıcıları, yürütme komitesi düzeyindeki bağlılık beyanları, KPI tanımları, listesi ve öncelik düzeyleri belirlenir.

Yıllık yol planında, her bir kıdemli liderlik takımı (SLT) ve dönüşümcü liderlik (TLT) takımı üyesinin bağllıı beyanı detaylandırılır ve opsiyonel olarak politika beyanlarından bahsedilir. Tüm SD'lerin ve SPG'lerin üst yönetim ekibinden bir veya birden fazla sponsoru bulunur. Ekim ayı başında, SD'lerin sponsorları, SLT ve TLT üyeleri ve pek çok farklı fonksiyondan ekiplerinin çapraz katılımı ile gerçekleştirilecek bir dizi strateji çalıştayı kurgularlar. Bu çalıştaylara, tüm kademelerden çalışanlar dahil olur ve böylelikle herkes strateji içeriğine katkı yapma şansı bulur. Bu çalıştaylarda, SPG'lerin altındaki SP'lerin belirlenmesi için ve ilgili fonksiyonel birimlerin SPG'lere yapabilecekleri katkılar hakkında girdi toplanması hedeflenmektedir. Çalıştaylarda, yukarıdan gelen (top down) SD ve SPG'lerin alt kırılımları, aşağıdan yukarıya doğru (bottom up) çalışılarak SP’lerin belirlenmesine katkı yapılır. Mevcut SPG ve SP'ler de bu çalıştaylarda değerlendirilir ve gerekli revizyonlar yapılır. 
Tipik bir çalıştay şu şekilde olur. Açllışta SD sponsoru, SD'yi ve altında belirlenen SPG'lerin içeriğini, genel stratejiye katkısını ve hedeflerini anlatır. Sonrasında, SPG'lere hizmet edecek görüşler, fikirler ve proje önerileri (SP'ler) toplanır ve öneriler katılımcılar tarafından oylanarak önceliklendirilir. Çalıştay sonrasında, SP'lerin taslak tanımları (charter), SD sponsorları tarafından belirlenen proje liderleri tarafından hazırlanır. Taslak SP tanımları SLT ve TLT üyelerinin görüşüne sunulduktan sonra, proje ekipleri, KPI'lar ve proje planları son haline getirilir.

Aynı zamanda, Ekim ayı sonunda, SLT ve TLT'nin katılımıla kurumsal KPI'lar son haline getirilir, CEO'nun bağlılık beyanı netleştirilir, SP'ler önceliklendilir. Aralık başına kadar tüm SP'ler BIPP'e girilir ve yol planı bağlılık beyanı kitapçığı yayımlanır. Bu kitapçık ile tüm fonksiyonel birimlerin ve Brisa' nın kurumsal scorecard'ı netleşmiş olur. Aralık sonunda ise bireysel seviyeye indirilmiş, kişisel SMART hedefler Brisa'nın bireysel KPI ve performans takip portali olan BRINSAN'a girilir.

Tüm strateji süreci tamamlandıktan sonra Aralık ayı sonu veya Ocak ayı başında tüm birim ve çalışanların katılımı ile bir vizyon toplantısı (yıllık paylaşım toplantısı) gerçekleştirilir. Bu toplantıda, yeni dönemin $(X+3)$ vizyonu ve stratejik hedefleri kurumun geneliyle paylaşlır. Bu toplantı ile, tüm çalışanların dünya ve sektör nereye gidiyor, bu trendler içinde biz neredeyiz ve nerede gitmek istiyoruz ve gitmek istediğimiz yere ulaşmak için hep birlikte yapmamız gereken şeyler nelerdir konularında bilgilendirilmesi ve bir ortak anlayışa erişilmesi amaçlanır.

Yıllık paylaşım toplantısını takiben, rutin olarak her üç ayda bir kurum çapında strateji açık oturumları gerçekleştirilir. Bu toplantılar periyodik olarak hem hizalanma hem de sorgulama imkânı yaratarak strateji sürecine anlamlı katkılar yapmaktadır. Ayrıca, BIPP içinde tüm yıl süresince açık olan inovasyon önerileri toplayan bir mekanizma bulunmakta ve BRINSAN aracılığıyla tüm çalışanların KPI'larının SD’lere bağlı ve SD'ler ile sürekli uyumlu olması sağlanmaktadır.

\section{Bulgular}

\section{Brisa'nın strateji uygulama yetkinliği}

Bu bölümde, Brisa' nın strateji süreci, geliştirilen teorik çerçevede 'strateji uygulama yetkinliği' bakış açısı ile değerlendirilmektedir. Brisa' nın strateji uygulama yetkinliğinin üç öncülü olan stratejik katılım, uyum ve bağlılık değişkenlerine katkıda bulunan uygulamalar sunulmaktadır.

Lastik endüstrindeki dönüşüm ve onu takip eden Brisa'daki zihniyet değişiminin strateji süreçleri üzerindeki ilk etkisi, strateji formülasyonunda görülmektedir. Bir hareketlilik çözümleri sağlayıcısı olarak Brisa, yarattı̆̆ı yeni müşteri değerleri doğrultusunda kendisine yön gösterecek daha kapsamlı stratejik analizler yapmaya başlamıştır. Daha önce sadece lastik ile ilgili trendler, veriler, göstergelerin incelenmesi yeterli olmaktayken, değişen pazar dinamiklerinin zorunlu kıldığı zihniyet değişimi sonrası Brisa oldukça kapsamlı ve veri odaklı stratejik çevre analizleriyle kendisini güncellemiştir. Çevre analizi, makro trendler ve senaryo çalışmaları, veri bilimciler tarafından 150'nin üzerinde parametrenin son 10-20 yılının analizi ve gelecek öngörüleri ile anlamlandırılmaktadır. Genel ekonomi, sektör ve pazar ile trendleri büyük veri analizleri ile belirlenmektedir. Makro ekonomik trend verileri, binek ve ticari araçlardaki mega trendler, pazar ve finansal veriler, tüketici eğilimleri detaylı bir biçimde sayısal yöntemlerle çalışılarak olası gelecek senaryolarına girdi sağlamaktadırlar. Bu veri odaklı yaklaşım ve çaba, formüle edilen stratejilerin gerçeğe daha yakından dokunması açısından değer taşımaktadır.

Ancak daha önce beş yıllık $(X+5)$ olarak yapılan orta vadeli planlamanın üç yıla $(X+3)$ indirilmesi, Brisa'nın bulunduğu çevredeki yüksek belirsizlik koşullarına işaret etmektedir. Değişken, belirsiz, karmaşık ve muğlak çevresel koşullarda, formüle edilen stratejilerin en iyi strateji olduğu ve geleceğin gerçekliğini net bir biçimde tahmin ettiği söylenemez (Bourgeois, 1985; Eisenhardt ve Bourgeois, 1988). $\mathrm{Bu}$ koşullarda, organizasyonun üst kademelerince belirlenen ve aşağıya empoze edilen stratejilerin kalitesine şüphe ile yaklaşmak ve uygulama sürecinde orta ve alt kademeler tarafından önerilen strateji revizyonlarına açık olmak gereklidir (Raes vd., 2011). Dolayısıyla, Brisa' nın faaliyet gösterdiği çevrede, strateji uygulama yetkinliğini ön plana çıkmaktadır.

Brisa strateji içeriğinin yapıtaşları olan stratejik sürücüler (SD'ler), strateji literatüründe kurumun stratejik önceliklerine (strategic priorities) tekabül etmektedirler (Kellermanns, Walter, Lechner ve Floyd, 2005). Bu öncelikler, strateji uygulama yetkinliği için, stratejik uyum ve bağlılığın sağlanacağı içeriği oluştururlar. Stratejik niyet ise, bu önceliklerin (sürücülerin) hangi temellere dayandırılarak, neden seçildiği ile ilgilidir. Brisa'da stratejik önceliklerin, bir analoji ile görselleştirilmesi (i.e., yelkenli gemi) ve hikâyeleştirilmesi stratejinin çalışanlar arasında bilinirliği için ve daha da önemlisi stratejik niyetlerin benimsenmesi için büyük fayda sağlamaktadır. Aynı zamanda, Brisa'nın strateji içeriğindeki hiyerarşik yapı (SD>SPG>SP) çalışanlara, gündelik yaptıkları işlerin büyük resmin neresine oturduğu, 
dolayısıyla kurumun geleceğinin yaratılmasına nasıl katkıda bulunduklarının haritasını sunmaktadır. $\mathrm{Bu}$ harita çalışanların stratejileri anlamlandırmalarına ve dolayısıyla da stratejik bağlılıklarının artmasında anlamlı bir etmendir.

Brisa strateji süreçlerinde, aynı zamanda, yoğun bir uygulama odağ1 göze çarpmaktadır. Strateji tasarımının ikinci ve üçüncü safhalarda, özellikle bütçeleme ve yol haritası çıarma esnasında yüksek ve kapsamlı bir katılım gözlemlenmektedir. Stratejik sürücüler projelendirilirken, farklı birimlerden ve çeşitli hiyerarşik kademelerdeki çalışanlardan proje önerileri gelmektedir. Mevcut projelere katkı taahhüdü verilirken ise her birim kendi uygulama kapasitesini göz önünde bulundurmaktadır. Böylelikle, üst düzey stratejik sürücüler, bilinçli bir şekilde ayakları yere basan stratejik projelere dönüştürülmektedirler. Stratejik öncelikler, organizasyon içinde daha geniş bir kitle tarafından anlaşılabilecek, gündelik eylemlerin diline çevrilmektedir. Stratejilerin projelendirilmesinde görev alma, projelere taahhütte bulunma ve stratejileri anlamlandırabilme, Brisa çalışanlarının stratejik katılım, uyum ve bağlılığına katkıda bulunmaktadır.

Brisa'nın yıllık yol planındaki stratejik katılım, formüle edilen stratejileri sağduyu ve ortak akıl süzgecinden geçirerek uygulama planlarına dönüştürmektedir. Katılımcılık, birimler arasında ve birim içinde çalışanlar arasında bir ortak anlayış ve fikir birliği sağlanmasına imkân vermekte ve stratejilerin arkalarında yatan temel nedenlere hizmet edecek şekilde eyleme geçirilmesini sağlamaktadır. Yani hem stratejik uyumu arttırmakta hem de strateji uygulama yetkinliğine hizmet etmektedir. Birim ve bireysel düzeyde üzerinde anlaşılan KPI'lar, uygulama sürecindeki sorumluluğu somutlaştırmakta, hedefleri netleştirmekte ve projelerin sürekli olarak sorumluları tarafından gerçeklik testlerine tabi tutularak gerekli revizyonların yapılmasına yol açmaktadırlar. Böylelikle, eylem ile stratejik niyet uyumu sağlanarak strateji uygulama yetkinliği arttırılmaktadır. Aynı zamanda, BRINSAN ve BIPP platformları, stratejilerin eyleme dönüştürülmesinin takibine merkezi bir destek vermektedirler. Bu platformlar da stratejilerin hayata geçirilmesi için gösterilen çabaları hem koordine hem de teşvik etmektedir.

Orta vadeli planlama esnasında yapılan değerlendirme anketi, Brisa'daki stratejik uyumu ölçme ve arttırma konusunda yapılan en somut eylemlerden birisidir. Bu anket, hem bütünsel olarak stratejiler hakkındaki ortak aklı ortaya koyarak, hem de icra seviyesindeki yöneticiler ile orta düzey yöneticilerin stratejik uyum gösterdikleri ve göstermedikleri konuları belirleyerek, Brisa'nın strateji uygulama yetkinliğine katkı yapmaktadır.

Brisa'nın strateji uygulama yetkinliğine katkı yapan bir diğer etmen de strateji sürecinde rol alan ekiplerin yapısı ile ilgilidir. Kıdemli liderlik takımının (SLT'nin) Brisa'nın mevcut becerilerinden daha fazla istifade ederek (exploitation) sürdürülebilir büyüme odağı varken, dönüşümcü liderlik takımının (TLT'nin) ise Brisa'yı gelecekte başarıya götürecek becerileri keşfederek (exploration) kurumun dönüşümün sağlanması odağı var. Stratejilerin formülasyonu ve uygulanmasındaki bu dengeli görev paylaşımı (ambidexterity) Brisa' nın strateji süreçlerinin önemli bir yetkinliği olarak ortaya çıkmaktadır.

Brisa'da stratejik bağlılı̆̆ın sağlanmasına hizmet eden bir öğe de başarılı işlerin hikâyeleştirilmesi (İzz Bırakanlar) ve çeşitli kurum iletişim kanalları aracılığı ile paylaşılmasıdır. Benzer şekilde, Brisa'da başarısızlıkların da bir öğrenme aracı olarak kullanıldığını görülmektedir. Bu faaliyetler stratejiyi kurum içinde ön plana çıkartarak, bilinirliğine ve kritik olarak yaklaşılmasına katkı verdiği için de strateji uygulama yetkinliğine faydalıdır.

Özetle, Brisa'nın strateji süreci geliştirilen teorik çerçeve kapsamında incelendiğinde, stratejilerin oluşturulmasına katılımın kurumda yaygın bir şekilde uygulandığını, farklı birimler arasında uyum sağlanmasının pek çok mekanizma ile sağlandığını ve tüm çalışanlarda stratejilere bağlılık yaratılmasının etkin bir şekilde önceliklendirildiğini görüyoruz. Bu bulgular, Brisa'nın yüksek strateji uygulama yetkinliğine sahip olduğunu gösteriyor.

\section{Tartışma ve sonuçlar}

Bu bölümde, araştırma bulgularının literatüre sunduğu teorik katkılar ve yöneticilere öneriler tartışılmaktadır. Ayrıca çalışmanın kısıtları bahsedilmekte ve gelecekteki araştırmalar için öneriler sunulmaktadir.

Bu çalışma, strateji süreçleri literatürüne strateji uygulama yetkinliği bakış açısını kapsamlı bir şekilde tanımlayarak ve bu yetkinliğin üç temek bileşenini ortaya koyan bir teorik çerçeve geliştirerek katkıda bulunmaktadır. Bu bağlamda, Brisa strateji süreci vakasının analizi, geliştirilen teorik çerçevenin gerçek hayata tatbik edilmesi ile önemli bulgular ortaya koymaktadır. Stratejilerin oluşturulmasının uygulama sürecinin içine yayılması, stratejik sürücülere hizmet edecek stratejik projelerin tüm kademelerden yeni stratejilerin ortaya çıkmasına imkân verecek şekilde yüksek katılım ile belirlenmesi ve süreç 
katılımcılarının stratejilerin arkasında yatan niyetler hakkında ortak anlayışa ve stratejilere bağlilığa sahip olmaları kurumun üstün strateji uygulama yetkinliğine işaret etmektedir. Katılım, uyum ve bağlılık ile şekillenen bu yetkinlik, kurumun birbirinden bağımsız parçalarının birbirleriyle ahenkli bir şekilde çalışmasını sağlar. Kurumdaki tüm birimler ve her kademedeki çalışanlar yeni stratejiler önerme konusunda sorumlu ve yetkin olurlar. Çalışmada ortaya konan bu yeni yaklaşım, geleneksel strateji süreci bakış açısının yetersiz kaldığı öngörülemez ve belirsiz çevresel koşullar altında tamamlayıcı bir rol üstlenmektedir (Hutzschenreuter ve Kleindienst, 2006).

Aynı zamanda strateji uygulama yetkinliği, strateji sürecini bir dinamik yetkinlik olarak konumlandıran literatüre de katkıda bulunmaktadır (Brews ve Hunt, 1999; Ramanujam ve Venkatraman, 1987). Strateji uygulama yetkinliğini geliştiren bir kurum, iş süreçlerini yeni operasyonel yetkinlikler geliştirmek için de kullanabilir (Eisenhardt ve Martin, 2000). Brisa strateji süreçlerindeki yıllar içinde bahsedilen değişiklikler de bunu göstermektedir.

Vaka analizi bulguları, yöneticiler için de önemli dersler içermektedir. Brisa her ne kadar strateji uygulama yetkinliğini zaman içinde yüksek dereceye getirmiş bir kurum olsa da çeşitli potansiyel gelişme alanları da mevcuttur. Brisa'da stratejik katılımın oldukça geniş kapsamlı ve derin olduğu gözlemlenmiştir. Stratejik katılım, stratejik uyum ve bağlılığı da tetiklediği için, bu çok önemli bir üstünlük olarak ele alınmaktadır. Ancak, Brisa'daki stratejik katılımın üst ve orta düzey yöneticiler etrafında yoğunlaşmakta ve operasyon yöneticileri ve hiyerarşinin alt seviyesindeki beyaz ve mavi yakalı çalışanların ise sadece ilgili strateji projeleri kapsamında sürece dahil olmaktadırlar. Benzer şekilde strateji değerlendirme anketi, üst ve orta düzey yöneticilerin stratejik uyumunu ölçmeye odaklanmıştır. En alt düzeydeki çalışanların stratejik uyumu ve bağl1lığı hakkında bir ölçümleme yapılmamaktadır. Elbette, tüm çalışanların strateji formülasyonuna üst ve orta düzey yöneticilerin getirdiği perspektifi getirmesi beklenemez; operasyon yöneticileri, beyaz ve mavi yaka çalışanlar stratejinin bütününü ve kendileri ile ilgili olan stratejik öncelikler haricindeki diğer öncelikler arasındaki önemli bağları göremeyebilirler. Ancak, tüm çalışanların strateji süreçlerine dahil olmasının hem ıraksak (divergent) fikirlerin de duyulması hem de bağlılı̆̆ın sağlanmasındaki olumlu etkileri araştırmalarda raporlanmıştır (Dooley vd., 2000; Fedor, Caldwell ve Herold, 2006; Tarakci vd., 2018). Stratejik katılımın kapsamının daha da geliştirilmesinin, yüksek maliyetli olmayan etkin yöntemleri arasında strateji açık oturumları (town hall meetings), strateji wiki'leri, sanal arama konferansları ve çevrimiçi öneri sistemleri sıralanabilir.

Yukarıdaki nokta paralelinde, Brisa strateji süreçlerine dış paydaşların (sektörel uzmanlar, teknik uzmanlar, tedarikçiler, bayi temsilcileri, bilim insanları, ilgili belediyeler, sivil toplum kuruluşları, vb.) da katılması düşünülebilir. Bu paydaşların katkılarıyla, Brisa hem stratejik karar kalitesini arttırabilir hem de daha geniş bir çevreye stratejilerinin -ve stratejileriyle somutlaşan kurumsal kimliğininmeşrutiyetini (legitimacy) duyurmuş olur. Çevresel belirsizliğin yüksek olduğu koşullarda, stratejilerin dış paydaşlar gözündeki meşrutiyeti rekabet avantajı sağlamaya katkıda bulunur (Payne, Cruz-Suarez ve Prado-Román, 2018). Dolayısıyla, Brisa 'açık strateji' kavramının temel bileşenlerini kendisine adapte ederek uygulama yoluna gidebilir (Hautz, Seidl ve Whittington, 2017).

Stratejiler konusunda ortak bir anlayış oluşturmak ve çapraz ekipler arasında uyum sağlamak Brisa strateji sürecinin önemli bir parçasıdır. Stratejik uyum, strateji sürecinin ilk adımı olan değerlendirme anketinde ölçümlenmektedir. Stratejik sürücülere ve stratejik proje gruplarına üst ve orta düzey yöneticiler tarafından atfedilen önem ve performansları bu anket ile sayısallaştırılmakta ve farklı seviyeler arasındaki fikir ayrılıkları incelenmektedir. Bu incelemenin sonuçları, stratejiler üzerine bir diyalog süreci başlatmaktadır. Bu nedenle, strateji değerlendirme anket çalışması çok değerlidir. Ancak, bu çalışmanın da geliştirilebilecek noktaları bulunmaktadır. İlk olarak, anket sadece strateji içeriğinin önemi ve performansı üzerine, sadece orta ve üst düzey yöneticiler tarafından doldurulmaktadır. Anketin, tüm çalışanların stratejilerin bilinirliğinin, stratejiler üzerindeki fikir birliğinin ve stratejilere bağlılığını ölçecek şekilde genişletilmesi oldukça kolay ve faydalı olacaktır. İkinci olarak, strateji içeriğinin ötesinde, anket çalışması stratejik uyumu ve hatta strateji sürücülerinin performanslarını tahmin edecek çeşitli öncülleri (birim içi güven, politik davranış düzeyi, yenilik iklimi, liderlik, öğrenme odağı, vb.) de içerebilir. Böyle bir anket stratejik uyumun sağlanmasında aracı olacak ve stratejik uyumun önemli gerçekleştiricilerini de ortaya koyacaktır.

Bir diğer potansiyel gelişim alanı anket sonuçlarının değerlendirilmesi ile ilgilidir. Anket ile toplanan veri, stratejik uyumu ölçme ve görselleştirme amacıyla geliştirilmiş stratejik konsensüs haritalaması (Tarakci vd., 2014) gibi daha ileri metotlar_ile değerlendirilebilir. Brisa strateji ekibinden edinilen veriler ile birimler arası stratejik konsensüs haritalandığında, bazı stratejik konularda yüksek uyum gözlemlenmekteyken, bazı stratejik konularda oldukça düşün stratejik uyum görülmektedir. Şekil $6^{\prime}$ da soldaki panel Brisa'daki fonksiyonel birimlerin SD2 hakkındaki, sağdaki panel ise SD5 hakkındaki 
stratejik uyumunu haritalandırmaktadır. Her bir birim bir daire ile ifade edilmiştir. Dairelerin büyüklüğü birim içi stratejik uyum düzeyini, dairelerin birbirlerine yakınlıları ise birimler arası stratejik uyum düzeyini göstermektedir. Görüldüğü gibi SD2 konusunda, birimlerin daireleri daha büyük (yani birim için daha fazla fikir birliği ve ortak anlayış var) ve daireler birbirlerine daha yakındır (yani birimler arası uyum yüksek). Bu gözlemleri ise SD5'in haritası için söyleyemeyiz. Hem birim içi ortak anlayış hem de birimler arası hizalanma oldukça düşüktür. Bu metodun detayları ve çevrimiçi kullanılabilen yazılımına https://mtarakci.shinyapps.io/consensus/ bağlantısından erişilebilir.

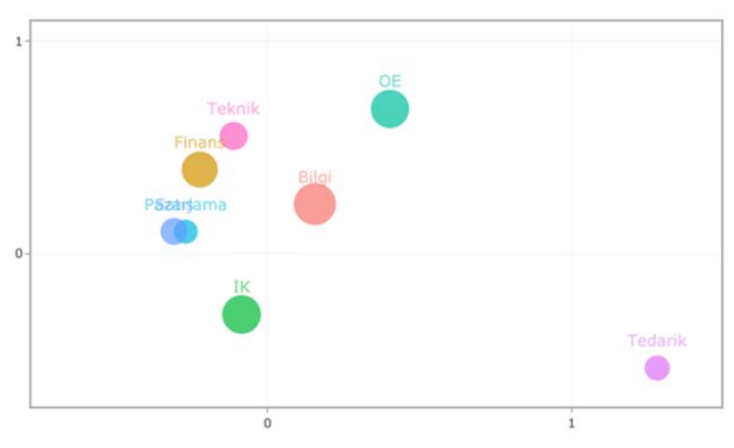

SD2 hakkında yüksek stratejik uyum

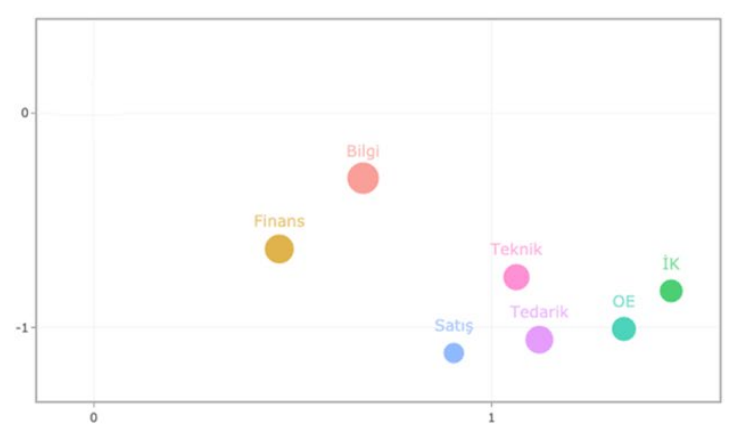

SD5 hakkında düşük stratejik uyum

Şekil 6: Stratejik konsensüs haritalaması

Kaynak: Yazar tarafından üretilmiştir.

Brisa'da, yol haritasının çıkartılması aşamasındaki geniş katılım, stratejik projeler bazında birim yöneticilerinin taahhütlerde bulunması, KPI'ların açı ve net olarak belirlenerek takip edilmesi gibi etmenler nedeniyle stratejik bağlılık genel olarak yüksektir. Ancak çalışanların bu bağlılığı stratejilerin bütününe mi yoksa sadece kendi görev alanlarındaki strateji projelerine mi olduğu net değildir. Strateji anketinde, bazı yöneticilerin çeşitli stratejik proje gruplarının önem ve performans değerlendirmelerini boş bırakması, stratejilerinin bütünü hakkında fikirlerinin olmayabileceği çıarımına sebep olmaktadır. Çalışanların stratejilerin bütününü anlaması, gerektiğinde kendi projelerinden ve hatta bireysel performanslarından kurum için iyi olanın yapılması için ödün verme fedakarlığını getirir (Amason, 1996). Stratejik bağlılığın stratejik uyum ile birlikte, uygulama yetkinliğine en büyük katkısı, tüm çalışanların aynı yönde efor sarf etmesini bağımsız olarak koordine etme kapasitesidir. Brisa da bu sorunun yanıtı netleştirilebilir.

Son olarak, belirsizlik koşullarının hâkim olduğu bir pazarda faaliyet gösteren Brisa, pazarı daha iyi analiz etmek için veri biliminin tekniklerinden faydalanmakta ve veri yoğun bir yaklaşım benimsemektedir. Bu çok değerli efor, pazarın geleceği ile ilgili yapılan tahminlerin geçerliliğini ve güvenilirliğini arttırır. Ancak, planlamanın yapıldığı andaki belirsiz ve tam olmayan bilgiye dayalı alınan kararlar çoğu zaman geleceği tutarlı bir şekilde öngöremezler (Eisenhardt, 1989). Zaman geçtikçe, açığa çıkan yeni bilgiler ışığında stratejik kararlar uygulama aşamasında gözden geçirilmelidir ve gerekli görülen revizyonlar yapılmalıdır (Wolf ve Floyd, 2017). Bu nedenle uygulamayı gerçekleştiren çalışanların, stratejik niyet ve varsayımlara hâkim olmaları ve bu gibi revizyonlar için teşvik edilmeleri gerekir. Brisa strateji uygulama sürecinde, strateji içeriğindeki gerekli revizyonların yapılmasını arttıracak bir öneri, BIPP'in benimsediği stage-gate yöntemini (projenin karar noktalarıyla birbirinden ayrılan safhalara bölündüğü bir proje yönetim yöntemi; şelale süreci olarak da bilinir), projenin değer yaratacağı müşteri ile daha sık etkileşim içinde olunmasını önceleyen çevik (agile) yöntemler ile birleştirmek olabilir. Kurum içinde bu yönde bir girişim de halihazırda gözlenmiştir; 2020 yılı itibarıyla bazı SP'lerin çevik yöntemler ile yönetilmeye başlaması ve bu konuda dış kaynaklardan destek alınması konuya halihazırda verilen önemi simgelemesi açısından oldukça olumludur.

Sonuçta, stratejik katılım, uyum ve bağlılık boyutları ele alındığında, Brisa'nın strateji uygulama yetkinliğinin oldukça yüksek olduğu kanaati oluşmaktadır. Bu bağlamda, önceki bölümde detaylandırılan Brisa'nın strateji sürecinin adımları, belirsiz, hızlı değişen ve karmaşık çevrelerde faaliyet gösteren, dolayısıyla formüle edilen stratejilerin geçerliliklerinin uzun süreler muhafaza edilemediği durumlarda, strateji uygulama yetkinliği inşa etmek isteyen firmalar için örnek gösterilebilir.

Tüm çalışmalarda olduğu gibi, bu araştırma da bazı kısıtlara sahiptir. Geliştirilen teorik model, tekli vaka analizi yöntemi ile çalışılmışır. Bu yöntem her ne kadar çalışmanın amacı ve kapsamı ile örtüşse de ilerideki çalışmalar farklı sektörlerde ve daha fazla sayıdaki organizasyonlarda strateji uygulama 
yetkinliğini inceleyebilir. Bu çalışmada sadece teorik olarak tanımlanan strateji uygulama yetkinliğini, güvenli ve geçerli şekilde sayısallaştırabilecek ölçekler geliştirilmesi gelecekteki çalışmalar için bir diğer alandır. Son olarak, bu çalışmada strateji uygulama yetkinliği ile kurumsal performans arasındaki ilişki incelenmemiştir. Kurumsal performans, tüm yönetim bilimleri araştırmaları için nihai bağımlı değişken olması itibariyle çok önemlidir ve gelecekteki çalışmalar strateji uygulama yetkinliğinin ne derecede ve hangi koşullarda kurumsal performans ile ilişkili olduğunu araştırabilirler.

\section{Hakem Değerlendirmesi / Peer-review:}

Dış bağımsız

Externally peer-reviewed

\section{Çıkar Çatışması / Conflict of interests:}

Yazar çıkar çatışması bildirmemiştir.

The author has no conflict of interest to declare.

\section{Finansal Destek / Grant Support:}

Yazar bu çalışma için finansal destek almadığını beyan etmiştir.

The author declared that this study has received no financial support.

\section{Teşekkür / Acknowledgement:}

Sabancı Holding Sanayi Grup Başkanı Cevdet Alemdar'a, Brisa Perakende ve Kilit Müşteri Satış Direktörü Numan Erdoğan'a, Brisa Kurumsal İletişim Müdürü Aylin Erdil'e ve Sabancı Yönetim Bilimleri Fakültesi Dekanı Prof. Dr. Nihat Kasap'a bu projeye verdikleri destek için teşekkürlerimi sunarim.

I would like to acknowledge the support of Sabancı Holding Industry SBU President Cevdet Alemdar, Brisa Retail and Key Accounts Sales Director Numan Erdoğan, Brisa Corporate Communications Manager Aylin Erdil and the Dean of Sabanci Business School Prof. Dr. Nihat Kasap.

\section{Kaynakça / References}

Amason A. C. (1996). Distinguishing the effects of functional and dysfunctional conflict on strategic decision making: Resolving a paradox for top management teams. Academy of Management Journal, 39 (1), 123-148.

Ashforth, B. E., \& Mael, F. (1989). Social identity theory and the organization. Academy of Management Review, 14(1), 20-39.

Ateş, N. Y., Tarakci, M., Porck, J. P., van Knippenberg, D., \& Groenen, P. J. (2020). The dark side of visionary leadership in strategy implementation: Strategic alignment, strategic consensus, and commitment. Journal of Management, 46(5), 637-665.

Beer, M. \& Eisenstat, R. A. (2000). The silent killers of strategy implementation and learning. Sloan Management Review, 41(4), 29-40.

Brews, P. J., \& Hunt, M. R. (1999). Learning to plan and planning to learn: Resolving the planning school/learning school debate. Strategic Management Journal, 20, 889-913.

Bourgeois III, L. (1985). Strategic goals, perceived uncertainty, and economic performance in volatile environments. Academy of Management Journal 28 (3), 548-573.

Bourgeois III, L. (1980). Performance and consensus. Strategic Management Journal, 1(3), 227-248.

Colbert, A. E., Kristof-Brown, A. L., Bradley, B. H., \& Barrick, M. R. (2008). CEO transformational leadership: The role of goal importance congruence in top management teams. Academy of Management Journal, 51(1), 81-96. 
Collier, N., Fishwick, F., \& Floyd, S. W. (2004). Managerial involvement and perceptions of strategy process. Long Range Planning, 37(1), 67-83.

David, F. R., \& David, F. R. (2017). Strategic management concepts and cases. Pearson Education Limited.

Dooley, R. S., Fryxell, G. E., \& Judge, W. Q. (2000). Belaboring the not-so-obvious: Consensus, commitment, and strategy implementation speed and success. Journal of Management, 26(6), 12371257.

Eisenhardt, K. M. (1989). Making fast strategic decisions in high-velocity environments. Academy of Management Journal, 32(3), 543-576.

Eisenhardt K. M., \& Bourgeois III, L. (1988). Politics of strategic decision making in high-velocity environments: Toward a midrange theory. Academy of Management Journal 31(4), 737-770.

Eisenhardt, K. M., \& Martin, J. A. (2000). Dynamic capabilities: What are they? Strategic Management Journal, 21(10/11), 1105-1121

Fedor, D. B., Caldwell, S. \& Herold, D. M. (2006). The effects of organizational changes on employee commitment: A multilevel investigation. Personnel Psychology, 59(1), 1-29.

Floyd, S. W., \& Lane, P. J. (2000). Strategizing throughout the Organization: Managing Role Conflict in Strategic Renewal. Academy of Management Review, 25(1), 154-177.

Floyd, S. W. \& Wooldridge, B. (1992). Middle management involvement in strategy and its association with strategic type: a research note. Strategic Management Journal, 13(1), 153-167.

Gerring, J. (2006). Case study research: Principles and practices. Cambridge University Press.

Gibbert, M., Ruigrok, W., \& Wicki, B. (2008). What passes as a rigorous case study?. Strategic Management Journal, 29(13), 1465-1474.

Gummesson, E. (2000). Qualitative methods in management research. Sage.

Grant, R. M. (2016). Contemporary strategy analysis, Text and cases edition. John Wiley \& Sons.

Guth, W. D., \& MacMillan, I. C. (1986). Strategy implementation versus middle management selfinterest. Strategic Management Journal, 7(4), 313-327.

Hambrick, D. C., \& Fredrickson, J. W. (2005). Are you sure you have a strategy?. Academy of Management Perspectives, 19(4), 51-62.

Hart, S. L. (1992). An integrative framework for strategy-making processes. Academy of Management Review, 17(2), 327-351.

Hart, S., \& Banbury, C. (1994). How strategy-making processes can make a difference. Strategic Management Journal, 15(4), 251-269

Hautz, J., Seidl, D., \& Whittington, R. (2017). Open strategy: Dimensions, dilemmas, dynamics. Long Range Planning, 50(3), 298-309.

Herold, D. M., Fedor, D. B., Caldwell, S., \& Liu, Y. (2008). The effects of transformational and change leadership on employees' commitment to a change: A multilevel study. Journal of Applied Psychology, 93(2), 346-357.

Hrebiniak, L. G. (2006). Obstacles to Effective Strategy Implementation. Organizational Dynamics, 35(1), 12-31.

Hutzschenreuter, T., \& Kleindienst, I. (2006). Strategy-process research: What have we learned and what is still to be explored. Journal of Management, 32(5), 673-720.

Jordan, A. H., \& Audia, P. G. (2012). Self-enhancement and learning from performance feedback. Academy of Management Review, 37(2), 211-231.

Kellermanns, F. W., Walter, J., Lechner, C. \& Floyd, S. W. (2005). The lack of consensus about strategic consensus: Advancing theory and research. Journal of Management, 31(5), 719-737.

Korsgaard, M. A., Schweiger, D. M. \& Sapienza, H. J. (1995). Building commitment, attachment, and trust in strategic decision-making teams: The role of procedural justice. Academy of Management Journal, 38(1), 60-84. 
Kotter, J. P. (1995). Leading change: why transformation efforts fail. Harvard Business Review, MarchApril, 59-67.

Lee, E. \& Puranam, P. (2016). The implementation imperative: Why one should implement even imperfect strategies perfectly. Strategic Management Journal, 37(8), 1529-1546.

Mael, F. A., \& Ashforth, B. E. (2001). Identification in work, war, sports, and religion: Contrasting the benefits and risks. Journal for the Theory of Social Behaviour, 31(2), 197-222.

March J. G., \& Simon H. A. (1958). Organizations. Wiley: New York. 2nd ed. 1993, Blackwell: Cambridge, MA.

Markoczy, L. (2001). Consensus formation during strategic change. Strategic Management Journal, 22(11), 1013-1031.

Mintzberg, H. (1973). Strategy-making in three modes. California Management Review, 16(2), 44-53.

Noble, C. H. (1999). The eclectic roots of strategy implementation research. Journal of Business Research, 45(2), 119-134.

Nutt P. C. (1999). Surprising but true: Half the decisions in organizations fail. Academy of Management Executive $13(4), 75-90$.

Payne, G., Cruz-Suarez, A., \& Prado-Román, A. (2018). Legitimacy as competitive advantage: A US airline case study. In: Díez-De-Castro E., Peris-Ortiz M. (eds) Organizational Legitimacy. Springer, Cham.

Porck, J. P., van Knippenberg, D., Tarakci, M., Ateş, N. Y., Groenen, P. J., \& de Haas, M. (2020). Do group and organizational identification help or hurt intergroup strategic consensus?. Journal of Management, 46(2), 234-260.

Porter, M. E. (2008). On competition, updated and expanded edition. Harvard Business Review Book, Boston.

Porter, M. E. (1997), Competitive Strategy. Measuring Business Excellence, 1(2), 12-17.

Raes, A. M. L, Heijltjes, M. G, Glunk, U., \& Roe, R. A. (2011). The interface of the top management team and middle managers: A process model. Academy of Management Review, 36(1), 102-126.

Ramanujam, V., \& Venkatraman, N. (1987). Planning system characteristics and planning effectiveness. Strategic Management Journal, 8(5), 453-468.

Sedikides, C., \& Gregg, A. P. (2008). Self-enhancement: Food for thought. Perspectives on Psychological Science, 3(2), 102-116.

Tarakci, M., Ates, N. Y., Porck, J. P., van Knippenberg, D., Groenen, P. J., \& de Haas, M. (2014). Strategic consensus mapping: A new method for testing and visualizing strategic consensus within and between teams. Strategic Management Journal, 35(7), 1053-1069.

Quinn, J. B. (1980). Strategies for Change: Logical Incrementalism. Macmillan, New York.

Wolf, C., \& Floyd, S. W. (2017). Strategic planning research: Toward a theory-driven agenda. Journal of Management, 43(6), 1754-1788.

Wooldridge, B., \& Floyd S. W. (1990). The strategy process, middle management involvement, and organizational performance. Strategic Management Journal, 11(3), 231-241.

Wooldridge, B., Schmid, T., \& Floyd SW. (2008). The middle management perspective on strategy process: contributions, synthesis, and future research. Journal of Management, 34 (6), 1190-1221.

Yin, R. K. (2009). Case study research: Design and methods (Vol. 5). Sage. 